\title{
Considering user profiles and occupants' behaviour on a zero energy renovation strategy for multi-family housing in the Netherlands
}

\author{
O. Guerra-Santin • H. Bosch • P. Budde • \\ T. Konstantinou $\cdot$ S. Boess $\cdot$ T. Klein $\cdot$ S. Silvester
}

Received: 7 November 2016 / Accepted: 23 January 2018 / Published online: 26 February 2018

(C) The Author(s) 2018. This article is an open access publication

\begin{abstract}
A number of facade solutions have been developed in recent years to solve the problem of largescale renovation of housing. In the Netherlands, housing associations have the ambition to achieve an energyneutral renovation approach, and so, some aim at energy neutrality. However, few address the complexity of multi-family rental dwellings and more importantly, the importance of user behaviour in the actual performance of the buildings. In current approaches, the zero energy target is sought for an average household. In this paper we present an approach to zero energy renovation in which the influence of occupants' behaviour in building performance is taken into account to eliminate the uncertainties related to energy savings. The results are used to inform the design process regarding the amount of energy production required to reach zero energy performance, and the feasibility of the on-site energy production only with photovoltaic panels. The research
\end{abstract}

O. Guerra-Santin $\cdot$ S. Boess $\cdot$ S. Silvester Faculty of Industrial Design Engineering, Delft University of Technology, Delft, The Netherlands

O. Guerra-Santin $(\bowtie)$

Uniresearch BV, Delft, The Netherlands

e-mail: oguerrasantin@gmail.com

H. Bosch · P. Budde

Rotterdam University of Applied Sciences, Rotterdam,

The Netherlands

T. Konstantinou $\cdot$ T. Klein

Faculty of Architecture, Delft University of Technology, Delft, The Netherlands showed large statistically significant differences on energy consumption between the different household types, which could contribute to pre-bound effects if these differences are not considered when calculating energy savings and return of investments. When considering scenarios based on behaviour after renovation, the difference between the lowest and the highest heating demand is reduced to $34 \%$.

Keywords Occupants' behaviour · Building simulation . Zero energy

\section{Introduction}

Next to other motivations, such as housing stock upgrading, fuel poverty reduction or indoor environment improvement (Beillan et al. 2011; Silvester 1991; Jong 1992), the goal of building renovation projects is to reduce energy consumption without compromising thermal comfort. However, recent research has shown that low energy buildings do not always perform as expected (Fokaides et al. 2011; Doran 2005; Danielski 2012; Bell et al. 2010; Guerra-Santin and Itard 2012). Large differences between the expected and actual energy consumption have been found in dwellings with similar characteristics and large differences have been found on the energy consumption of different types of households (McLoughlin et al. 2012; Kane et al. 2015; Wei et al. 2014). The consequence of such differences is an uncertainty in actual energy savings, which affects the willingness to invest in low carbon technologies and 
far-reaching renovation projects. In addition, in social housing projects, the problems derived from the uncertainty related to the actual energy use are magnified by the different incentives for tenants and landlords.

A number of facade solutions have been developed in recent years to solve the problem of large-scale renovation of housing (Sijpheer et al. 2016). In the Netherlands, front-running housing associations have the ambition to achieve an energy-neutral renovation approach, and so, some façade solutions aim for energy neutrality such as Stroomversnelling and Prêt-à-loger (Stroomversnelling 2015; Pretalogger 2015). However, few address the complexity of multi-family rental dwellings and more importantly, the importance of user behaviour in the actual performance of the buildings. In current zero-on-the-meter approaches, the zero energy target is sought for an average household, under average (or ideal) building operation. In these projects, the residents pay for energy if their use exceeds the average that was calculated for their type of house (Sijpheer et al. 2016).

In this paper we present the 2 ndSkin ${ }^{1}$ approach to renovation. The goal of the 2 ndSkin project is to develop a zero energy solution for multi-family renovation projects in social housing. The renovation solution focuses on a reference building that has been identified as a type which, given the poor thermal quality of the construction and the number of units in the Netherlands, offers the best market and carbon emission reduction opportunities (Steenma et al. 2016). A detail account on the selection of the reference building can be found on Konstantinou et al. (2017).

The central case in the 2ndSkin project is the socalled porch apartment, a massively applied dwelling type not only in the Netherlands but also in the rest of Europe (Steenma et al. 2016). The large-scale renovation of this type of building is difficult because of its variance in shape, design and quality, and thus, zero energy renovation concepts for porch apartments have not been successful so far. For example, in a 418-unit demonstration project in the period 1989-1991 (Silvester 1991; Jong 1992), the actual energy savings

\footnotetext{
${ }^{1}$ The 2ndSkin approach was developed by Delft University of Technology in collaboration with BAM woningbouw, Hogeschool Rotterdam, Eneco Installatiebedrijven, Spee architecten, DGMR Raadgevende Ingenieurs and Zehnder-JE Storkair. The project was funded by TKI and BTA Climate Kic. The 2ndSkin renovation strategy is currently being applied to 12 houses in the Netherlands. There are no conflicts of interest in this paper.
}

were about $25 \%$ lower than expected and the average costs of the projects were far above the amount of money spent by social housing corporations on standard renovation at that time $(142 \%)$.

Important bottlenecks in the process are related to the users, the composition of the different options for renovation, the calculation of the increase of the rent related to the home improvements, the tenants' participation rate, the application of different solutions in one complex and the postponed application of renovation measures after mutation of renters who refused to participate in the first round (Matschoss et al. 2013; Mathiesen et al. 2016; Winter 1993; Beillan et al. 2011). Studies have shown that even though many improvements of the housing stock have been achieved, solutions mostly consist on basic maintenance and shallow renovation and so, deeper renovation measures are required (Filippidou et al. 2016).

Because of the Dutch government's ambition (Sociaal-Economische Raad 2012) to improve the Dutch building stock to energy neutrally in accordance with the Energy Performance of Buildings Directive adopted by the European Union (http://ec.europa.eu/ energy 2016), it is necessary to develop products and processes for renovating the multi-family (porch apartment) complexes within the existing housing stock. Previous experiences showed that there is still an enormous challenge to fulfil the ambition to make the porch apartment energy neutral and in an acceptable way for the residents.

Furthermore, the available budget for the renovation of social housing is limited. The maximum investment for the refurbishment has to be depreciated at least within the lifetime of the renovation. In addition, regulations might limit the maximum increase of the rent (for example in the Netherlands), according to the home improvement levels.

Therefore, the 2ndSkin technical solution has been visualised as a pre-fabricated facade that can be installed in a short period of time, limiting the nuisance for the occupants, and thus allowing them to remain in their houses during the installation process. Keeping occupants in their homes is needed to decrease the costs of the renovating process related to the relocation of occupants, and it could facilitate the acceptance of the occupants to take part in the renovation process. Furthermore, the challenge of the 2ndSkin project consists on the development of an approach that takes into account the influence of building operation and occupants' 
behaviour in the performance of the building in order to eliminate the uncertainties related to energy savings and payback periods. The renovation strategy aims to provide a zero-on-the-meter solution, taking into account the diversity of household living in the dwellings. This is a clear contrast with other studies on zero energy buildings, in which the zero energy performance is only aimed at an average or 'standard' occupancy. For this, the project follows an user-centred approach in order to minimise the performance gap and to increase the acceptability of the renovation among the tenants.

This paper shows the first insights into the relation between the ambitions of zero energy and the different groups of occupants and their energy-related patterns. The investigation focuses on the uncertainty that can be encountered before and after the renovation, and on the identification of ways to reduce such uncertainty. The results will be used to inform the design process regarding the amount of energy production required to reach a zero energy solution, and the feasibility of the on-site energy production only with photovoltaic panels, taking into account different occupancy and building characteristics scenarios.

Section 2 presents the approach used in this research (the 2ndSkin approach). Section 3 presents the investigation on user profiles and occupancy patterns for energy calculation. Section 4 shows the energy calculation results from the user investigation to determine occupants' behaviour and user profiles. Section 5 presents the results of the energy calculations and building simulations. To finalise, the discussion and conclusions are presented in Sections 6 and 7, respectively.

\section{The 2ndSkin approach}

The 2ndSkin approach consists on an integral renovation strategy for multi-family porch dwellings. The integral strategy involves four aspects: (1) a technical solution (the 'second skin' with integrated installations), (2) an acceptability process, (3) an occupancy evaluation process and (4) a new business model.

In order to develop the solution, a methodology was established not only to provide a solution to refurbish the case study building, but also to deliver knowledge and results that can be used in refurbishment tasks on national and European level. The methodology consisted on a design and research renovation strategy around a series of prototypes iterations. Early investigations in the project led to think that the direct replication of prototyping to an up-scaling phase may be a factor that hinders the project's decision-making. This is because some of the technologies to be implemented need to be further proven before their application and use on a large scale. More flexibility should be brought into the prototyping strategy, meaning that the prototypes will be used to test the construction, performance and the user interaction of technologies to be implemented in the up-scaling of the 2ndSkin approach. For this reason, the development of the 2ndSkin renovation strategy is based on a reference building. Design iterations proceed in parallel with the prototypes' development, benefiting from research results.

Within the 2ndSkin strategy, two concepts are thus, important: the reference building and the Dutch household typologies. Initial investigations and design are carried on these concepts as pre-step to actual projects or up-scaling projects. The following sections 'The reference building and technical solution' and 'Dutch household typologies' present the definitions of both concepts.

This paper presents one of the four aspects of the 2ndSkin approach: the occupancy evaluation process. The occupancy evaluation process intends to provide the necessary information to reduce the performance gap, and so, to provide more certainty on energy saving calculations and return of investments. The approach to the occupancy evaluation process, and its relationship with the technical solution design process, is introduced in 'Occupancy evaluation to reduce the performance gap' section.

As previously stated, the objective of the renovation process is to achieve a zero energy performance. In order to establish the design requirements of the renovation strategy, it is necessary to define the zero energy boundaries. The definition of the zero energy concept is presented in 'Definition of zero energy building' section.

The reference building and technical solution

A reference building is used to develop the 2ndSkin approach. The 2ndSkin approach aims at creating a solution that can be easily implemented in a type of building by making only a few bespoken decisions.

The target group for the present investigation are the post-war, porch apartment blocks (portieketagewoning) in the Netherlands. To define the reference building, 
literature research and an on-site investigation was carried out in the area of Rotterdam-Zuid. Systematic documentation of the building characteristics was conducted during on-site visits. A reference building type was determined, which is considered the most common type in the area of investigation while having typical characteristics found in the Dutch and European building stock. The reference building, as shown in Fig. 1, is a mid-rise apartment block with central staircase, accessible in the front façade, leading to two apartments per floor. Its construction characteristics are massive concrete wall and brick cladding with an intervening, noninsulated cavity, reinforced concrete slabs, continuous to the balconies, and large windows, incorporating lightweight parapet. Most of these dwellings are heated by individual local gas furnaces and central heating boilers. The domestic hot water is mostly provided by individual electric boilers or gas water geyser. The gas is supplied, in most cases, from the grid. It is important to add that this study focuses on energy demand, since the goal is to define the parameters that are important for the design phase of the 2ndSkin solution. In addition, it is foreseen that the solution, in practice, would be all-electric, since it is one of the conditions for the zero-on-the-meter category in the country (see 'Definition of zero energy building' section).

The 2ndSkin approach to achieve zero energy dwellings is based on decreasing the use of energy, then using sustainable energy sources as widely as possible and, finally, if using finite (fossil) energy sources is inevitable, they must be used efficiently and compensated with 100\% renewable energy (AgentschapNL 2013). Thus, the solution needs to combine the building envelope upgrade, the use of efficient building systems and the generation of energy.

Firstly, the building envelope is insulated with prefabricated sandwich panels. Then, existing windows are replaced. The pre-fabricated, floor-height, sandwich panels, featuring new windows and integrated services pipes, are attached to the substructure that consists of wooden posts connected to external facet of the existing structures through steel $U$ profiles. Heat recovery ventilation units are placed on the rooftop, while the ventilation pipes are integrated in an insulation board, attached to the sandwich panel that covers the opaque part of the existing façade. The proposed renovation solution results in the required thermal characteristics of the envelope, in terms of thermal resistance and infiltration, as well as providing and updated the building services' performance, as summarised in Table 2. Figure 2 shows graphically the 2ndSkin technical solution.

The 2ndSkin process differs from conventional renovation process in the fact that the technology is seen as independent from the underlying structure of the building, and integrated into the facade. The system integrates heating, ventilation and cooling into the skin so it can be easily accessible from the outside of the building, therefore facilitating the maintenance. Photovoltaic panels are also integrated in the skin in order to reach the zero energy targets. The flexibility of the system and the accessibility from the outside allow upgrading the installations in further phases of the development during the lifetime of the building, thus increasing the timespan of the initial investment. The flexibility of the system will also allow for its customization for different types of building archetypes, for different countries and for different climate zones.

\section{Dutch household typologies}

Energy consumption in dwellings is affected by household demographics (age, gender, household composition) (McLoughlin et al. 2012; Kane et al. 2015), socioeconomical level (education level, income) (Meyers et al. 2010; Wei et al. 2014) and lifestyle (retirement, full-time work, unemployment) (Kane et al. 2015; Yohannis et al., 2008). These factors are known to influence energy consumption and are considered to be very important because of the great variation within and between types of households. For example, two singleperson households could have very different energy consumption because of the age, background, employment status and health condition.

The most common type of Dutch households has been defined through analysis of the sociodemographic data of household living in the building stock. The identification of the most common household types is important for the project because the renovation is aimed at social housing in the Netherlands, and so it is likely that the occupants of these buildings hold special characteristics. These characteristics could have an effect on occupants' behaviour and energy consumption. In addition, targeting specific solutions according to occupants' characteristics can increase the acceptability of the project and it would help designers to make better choices regarding the final solution of the renovation.

The occupancy and heating patterns of the different household types will allow us to calculate more 


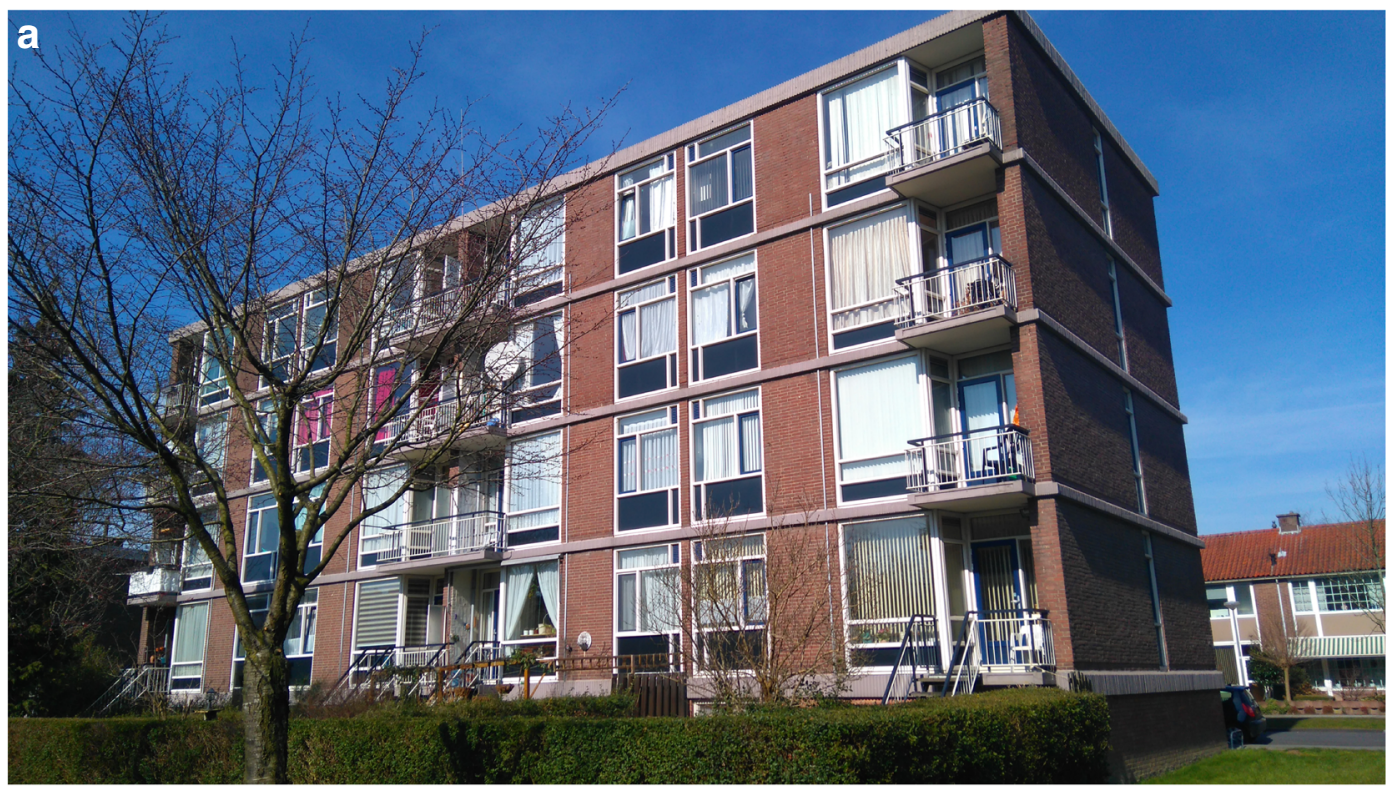

b

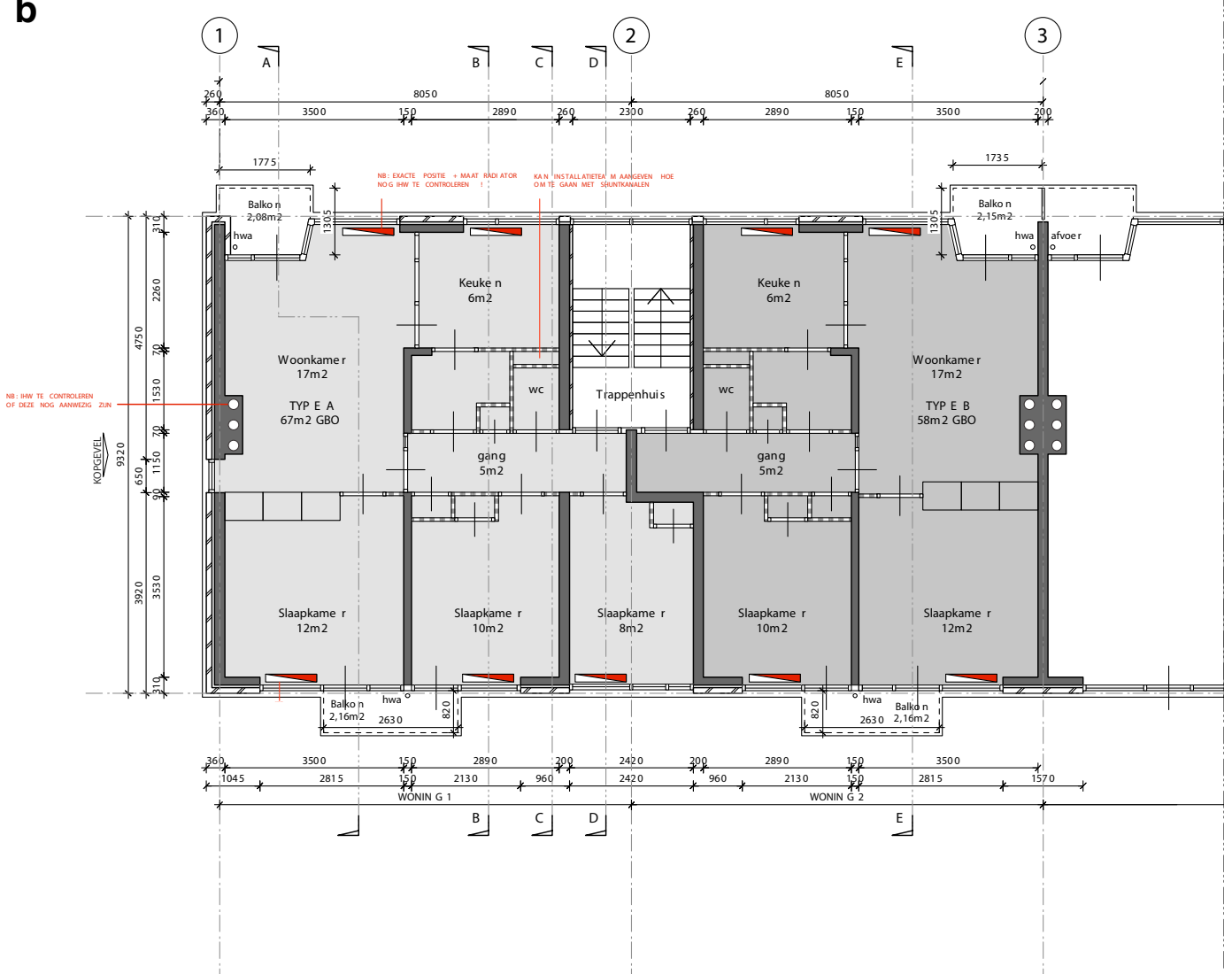

Fig. 1 Reference building floor plan (two apartments per floor)

accurately the expected building-related and userrelated energy demand, and thus to calculate more accurately the sizing of energy generation technologies.
The Dutch household typologies and their behaviours are investigated in 'Results: energy calculation' section. 
Fig. 2 The $2^{\text {nd }}$ Skin solution (

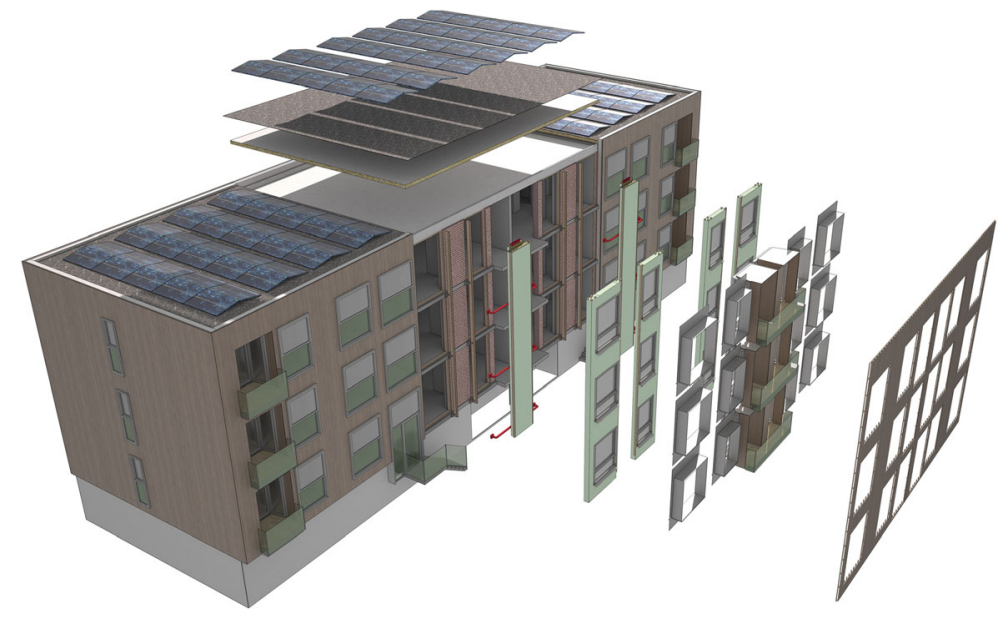

Occupancy evaluation to reduce the performance gap

Very low and zero energy renovation projects are associated with high costs and long payback periods. The actual performance of these buildings is often unpredictable due to the uncertainty provided by occupant behaviour (Virote and Neves-Silva 2012). This investigation aims at decreasing the performance gap, which is defined as the difference between the expected and actual energy consumption in buildings. This gap is created by rebound and pre-bound effects.

The pre-bound effect has been defined as the situation in which energy savings are lower than estimated due to the overestimation of energy consumption before the renovation. According to Sunikka-Blank and Galvin (2012), as renovations cannot reduce energy that is not actually consumed, this has implications for the economic viability of thermal retrofits. The expected energy consumption is, in some cases, higher than in reality because in building simulations an 'average household' and 'average building occupancy' are often employed. However, there is a large diversity in household characteristics, preferences and lifestyles of buildings' occupants, and therefore, large differences have been found between standardised occupancy patterns and actual occupancy patterns (Guerra-Santin et al. 2016).

The rebound effect has been widely studied in recent years. This effect can be defined as the increase on energy consumption in services for which improvements in energy efficiency reduce the energy costs (Herring and Sorrell 2009). Rebound occurs when people compensate for efficiency improvements by increasing their spending (Hens et al., 2010). In addition, it is important to consider that the rebound is in some cases not a consequence of the user's choices or behaviour, but a consequence of new technologies.

Rebound and pre-bound effects can be minimised by knowing better the context of the users, their actual requirements and their capacity for changing behaviour (Guerra-Santin 2017).

The objective of this research is to reduce uncertainties related to occupants' behaviour and household typology, by integrating user research into the design process. Figure 3 shows the approach used to integrate the results from the user research into the conceptual design process (e.g. before the detailed design). Two types of activities are shown in the figure: design iterations (black blocks) and user research (white and grey blocks). Diverse methods were used within the user research, such as statistical analysis, energy modelling and building simulations (quantitative methods), building monitoring evaluation of heating practices and comfort preferences (mixed methods), and investigation on mock-ups and case studies regarding occupants acceptability and requirements (qualitative methods). The user research was carried out in parallel to the technical conceptualisation of the solution, and was intended to feed back to the design process. The details of the approach can be found in Guerra-Santin (2017). This paper deals with quantitative methods to determine the energy demand, energy generation, the sizing of installations, and to evaluate the feasibility to reach a zero energy performance based on the technical solution.

\section{Definition of zero energy building}

According to Marszal et al. (2011), the most important issues to define a zero energy building are the metric of the balance, the balancing period, the type of energy use 


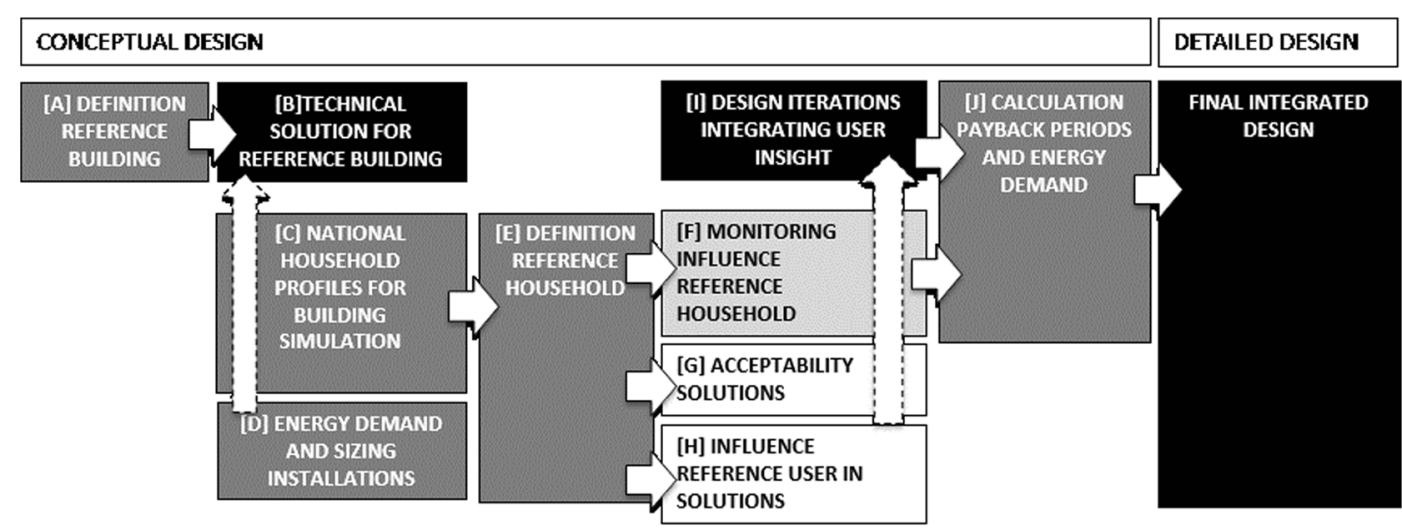

DESIGN ITERATIONS

QUANTITATIVE METHODS

\begin{tabular}{|c|}
\hline MIXED METHODS \\
\hline QUALTTATIVE METHODS \\
\hline
\end{tabular}

Fig. 3 Integration of user research into the design process of the technical solution

included in the balance, the type of energy balance, the accepted renewable energy supply options, the connection to the energy infrastructure, and the requirements for the energy efficiency, indoor climate and buildinggrid interaction. This section discusses the issues that are relevant for the 2ndSkin strategy.

\section{Metric and period of the balance}

A primary energy demand method is in accordance to the EPBD (European Commission) and takes into account differences between energy sources, which can help to make decisions during the design phase. Primary energy demand is the preferred metric for the balance in most methodologies, which makes comparison to other projects easier. However, for the 2ndSkin project, we follow a method based on the more straightforward zero-on-the-meter approach (Nul-op-de-meter), since it is the approach used by the Dutch industry and by housing associations in the Netherlands, which are the target market group. The zero-on-the-meter approach is based on a balance, between annual energy demand and annual energy generation, which is also in line with the Energy Performance of Building Directly. The annual balance is also used because in Northern European countries, the zero energy targets would be difficult to reach otherwise, given the large differences on energy demand and production between summer and winter. Furthermore, this approach also intends to investigate a zero energy solution that can be reached without the investment on costly shared infrastructure. The annual energy demand has been calculated with the dynamic hour-to-hour building simulation program Bink. The results and details of the simulation are presented in 'Heating demand: building simulation' section.

\section{Type of energy use}

Two types of energy end-uses have been defined: building related and user related. Figure 4 aims at clarifying the differences between the classifications of energy end-uses.

Building-related energy consumption is the energy used for services related to the building itself, such as space heating and cooling, ventilation and lighting. These energy services can be directly influenced through design both in new and renovated buildings. These energy requirements can be reduced by delivering a better design (e.g. passive design) that allows the building to retain heat gains in winter, avoid heat gains in summer and maximise the use of natural light.

User-related energy consumption is considered to be mostly influenced by the building's occupants. Within user-related consumption, we can find the energy used for cooking, domestic hot water, and use of electric equipment and appliances. Although the use of energy-efficient appliances and electric equipment could reduce the energy consumption, the purchase of such products is mostly in the hands of the occupants. Designers and building regulators have almost no influence on these choices. 


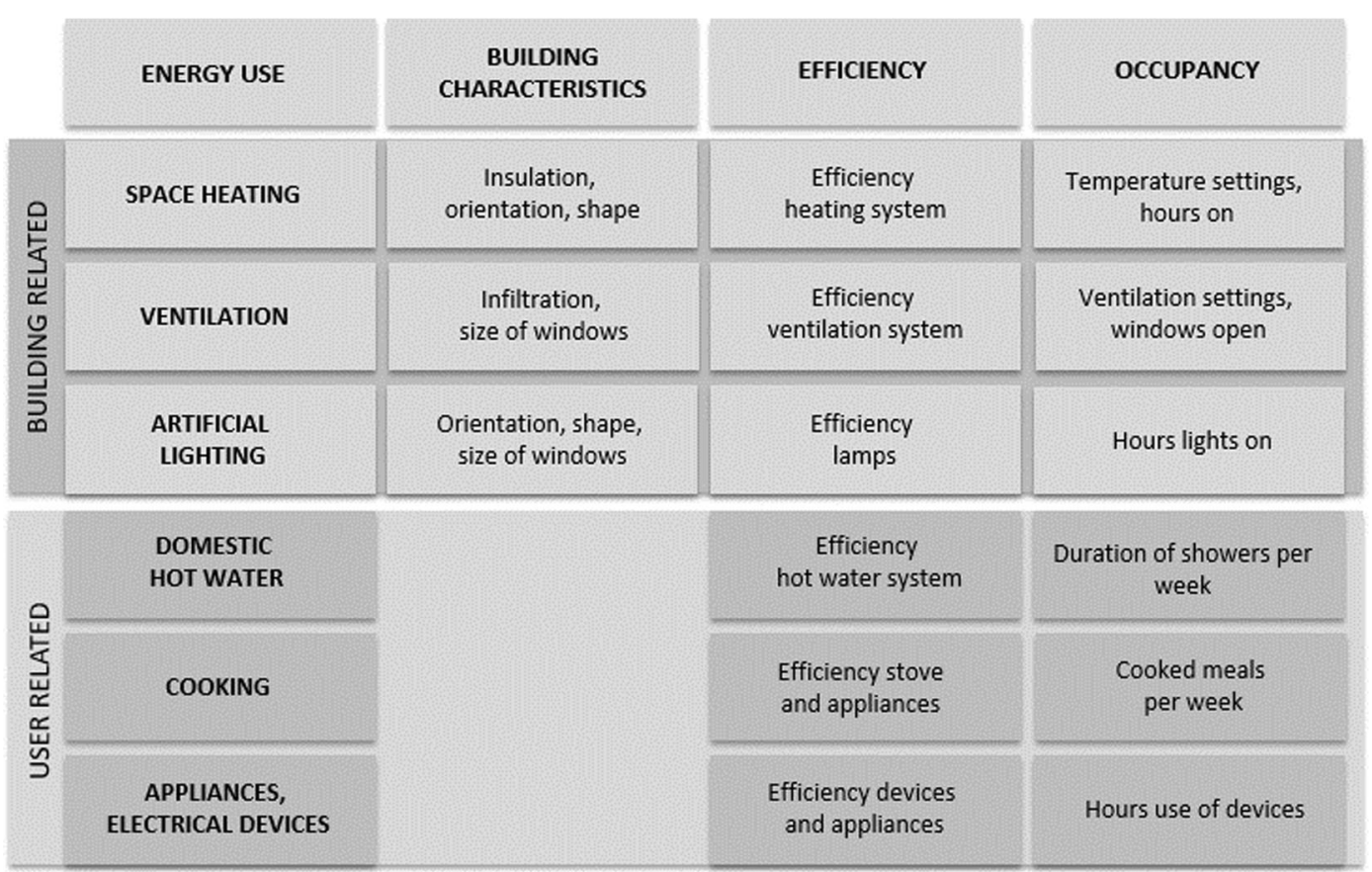

Fig. 4 Building-related and user-related energy end-uses

The zero-on-the-meter approach in the Netherlands includes both types of energy consumption. The business model currently followed by Dutch contractors provides tenants with new highefficiency kitchens or light bulbs (or vouchers for them). The 2ndSkin approach also seeks to further reduce user-related energy demand by providing the right feedback and controls to the residents of the buildings. However, the development of feedback and control solutions is out of the scope of this paper.

\section{Renewable energy supply options}

The Dutch zero-on-the-meter (nul-op-de-meter) approach allows the renewable energy to be generated off-site, but within a radius of $10 \mathrm{~km}$ (RVO, 2015). The need for off-site energy production will depend on the actual building to be renovated, since location, number of units per building, orientation and type of roof will affect the capacity for energy production. In this paper, we study the possibility of generating all the necessary energy to reach the zero energy performance only with photovoltaic panels, since these can be integrated in the technical skin solution.

\section{Zero energy system boundary}

The system boundary considered for the zero energy calculation, systems' dimensioning and calculation of the expected energy consumption, is based on one porch building (six to eight housing units depending on the number of storeys), since this is the basic unit of renovation possible, and they share a common roof and circulation areas.

\section{2ndSkin technical solution requirements}

Based on the market for the renovation strategy, the building regulations in the Netherlands and on the technical restrictions based on the reference building, the 2ndSkin solution requirements are the following:

- Integrated installations (heating and ventilation systems) into the façade panels.

- Integration of photovoltaic panels in the roof and potentially in the facades panels of the building, decreasing the costs for roofing and cladding.

- Energy generation through photovoltaic panels, to assess how far can the zero energy concept be reached solely within the 2ndSkin solution. 
The implications of the user profiles and occupants' behaviour for the zero energy renovation strategy will be discussed in 'Discussion' section, in which the results from the building simulations and energy calculations presented in sections 'Heating demand: building simulation', 'Domestic hot water' and 'Electricity consumption' are integrated to the energy generation scenarios presented in 'Energy generation' section. Following 'User profiles and occupancy patterns for energy calculation' section focuses on the investigation of occupants' behaviour and user profiles.

\section{User profiles and occupancy patterns for energy calculation}

As previously stated, research has shown that household type and lifestyle have a large impact on energy consumption. Thus, the first step to determine the interaction between users and buildings was to define the most representative types of households in the country of study.

The household types on a national level were defined according to household size and age of the household members, specially taking into account the presence of children and elderly people, groups that have shown to have an effect of energy consumption (Guerra-Santin and Itard 2010). For the investigation of Dutch households, the WoON 2012 dataset was used (Tigchelaar and Leidelmeijer, 2012). The dataset contains 69,000+ cases, from which $4800+$ include a building audit. The dataset included information on building characteristics, energy consumption, occupants' behaviour and household demographics. The resulting household typologies were as follows: single senior, single adult, seniors couple, adults couple, three adults, single parent household and nuclear family. The details of the analysis are presented in Guerra-Santin and Silvester (2016).

As stated previously ('The 2ndSkin approach' section), households living in the reference building might have different preferences, behaviour and lifestyles, and thus, different energy requirements than those of the average household in the Netherlands. To investigate such differences, an independent samples $t$ test was conducted between the energy use (gas and electricity) in the reference buildings, and the energy use in other types of buildings. The WoON dataset was split into a sub-dataset containing only the cases of building similar to the reference building: low rise (three to five levels) rental apartments built between 1946 and 1975. The sub-dataset contains 2194 cases. The results of the $t$ test on gas consumption showed that less gas is used in reference dwellings $\left(\mathrm{M}=1175, \mathrm{SD}=613.9 \mathrm{~m}^{3}\right.$ gas $)$ than in other buildings $\left(\mathrm{M}=1699, \mathrm{SD}=896.6 \mathrm{~m}^{2}\right.$ gas $), t=$ $38.9(2628.2), p<.001$. The results of the $t$ test on electricity consumption also showed that less electricity is used in reference dwellings $(\mathrm{M}=2139, \mathrm{SD}=$ $1131.9 \mathrm{kWh})$ than in other buildings $(\mathrm{M}=3424.6, \mathrm{SD}=$ $1774.8 \mathrm{kWh}), t=51.4(2629.5), p<.001$.

To determine the differences on energy consumption between household types, analysis of variance tests were carried out on the complete dataset (all building types) and on the subset containing only the cases determined as reference buildings. On the one hand, the ANOVA results on the complete dataset showed that there are statistically significant differences on gas $(\mathrm{F}(6,16,080)=659.1, p<.001$ Welch statistic $)$ and electricity $(\mathrm{F}(6,16,059)=3054.8, p<.001$ Welch statistic) consumption between all household types (see descriptive statistics in Table 1). On the other hand, the ANOVA results on the reference building subset showed that gas consumption $(\mathrm{F}(6,538)=10.7$, $p<.001$ Welch statistic) and electricity consumption $(\mathrm{F}(6,536)=39.5, p<.001$, Welch statistic $)$ are statistical significantly different for some types of households; energy use in smaller households is different to energy use in larger households (see descriptive statistics in Table 1). However, the differences on energy consumption between the household types in the reference buildings are not as large as in the complete sample.

Figure 5 shows in percentages, the difference on energy use per household in reference dwellings in comparison to all types of dwellings. The households in reference buildings use from $40 \%$ (single adults) to $70 \%$ (three adults) less energy in comparison to households living in all types of buildings. These results suggest that in the reference building, occupants' behaviour might have a smaller effect than in other types of buildings. This could be caused by the fact that all social rental apartments have similar characteristics, and by the fact that the households in these apartments tend to have lower incomes. Thus, to guarantee the building zero energy performance, we investigate the impact that household typology might have on energy demand.

In order to model occupants' behaviour in the building simulations, occupancy profiles per household type have been previously defined statistically using factor analysis and ANOVA tests (Guerra-Santin and Silvester 
Table 1 Descriptive statistics for gas, electricity and water consumption in all dwellings and reference dwellings

\begin{tabular}{|c|c|c|c|c|c|c|}
\hline & \multicolumn{3}{|c|}{ All dwellings } & \multicolumn{3}{|c|}{ Reference dwellings } \\
\hline & $N$ & $\begin{array}{l}\text { Gas }\left(\mathrm{m}^{3} / \text { year }\right) \\
\text { Mean }\end{array}$ & $\begin{array}{l}\text { Electricity }(\mathrm{kWh} / \text { year }) \\
\text { Mean }\end{array}$ & $N$ & $\begin{array}{l}\text { Gas }\left(\mathrm{m}^{3} / \text { year }\right) \\
\text { Mean }\end{array}$ & $\begin{array}{l}\text { Electricity }(\mathrm{kWh} / \text { year }) \\
\text { Mean }\end{array}$ \\
\hline Single senior & 6648 & $1521.0(908.2)$ & $2162.2(1143.7)$ & 293 & $1113.1(551.5)$ & $1724.2(857.4)$ \\
\hline Single adult & 11,429 & $1310.3(790.2)$ & $2341.3(1397.4)$ & 888 & $1069.7(583.5)$ & $1837.3(991.8)$ \\
\hline Adults couple & 13,056 & $1682.6(858.0)$ & $3479.4(1609.9)$ & 329 & $1185.7(604.1)$ & 2338.4 (1183.7) \\
\hline Seniors couple & 8236 & $1876.8(987.1)$ & $3358.3(1503.8)$ & 192 & $1241.7(558.4)$ & $2342.3(1048.9)$ \\
\hline Three adults & 3892 & $1914.6(856.7)$ & $4681.2(1816.4)$ & 80 & $1334.6(680.7)$ & $2725.8(1190.3)$ \\
\hline Single parent & 2202 & 1572.5 (749.6) & 3193.9 (1528.3) & 185 & $1328.3(765.1)$ & $2405.3(1127.5)$ \\
\hline Nuclear family & 13,021 & $1859.5(831.8)$ & 4309.1 (1708.6) & 227 & $1349.4(605.1)$ & 2772.9 (1243.9) \\
\hline Total & 58,484 & $1668.6(887.4)$ & $3341.4(1752.3)$ & 2194 & $1231.8(612.3)$ & $2306.6(116.9)$ \\
\hline
\end{tabular}

2016). The profiles of the household typologies can be seen in Fig. 6. The household profiles consist on occupancy profile (presence at home) and heating use pattern (use of thermostat and radiators) per household type. Figure 6 shows the household typologies and their behaviours according to the intensity of energy use (more energy intensive vs. less energy intensive) and according to household size (smaller vs. larger household).

The results showed that, regarding presence at home, households with seniors and nuclear families tend to spend more time at home, while single adults and adult couples spend less time at home. Regarding the use of the thermostat, seniors showed to set the thermostat to a higher temperature than other households while single adults showed to set thermostat to a lower temperature than other households. In addition, single seniors, nuclear families and households with three adults showed to setback their thermostat to a higher temperature. Concerning the use of radiators, households with children showed to heat more often the bedrooms than other households, while households with three adults heat less often the bedrooms.

In general, the least energy intensive behaviours were found in households with one adult and single parent household, while the most energy-intensive behaviours were found in households with seniors and nuclear families. The calculation results for the expected building-related and use-related energy consumption per household type are presented in the following section.

\section{Results: energy calculation}

In this section, the energy calculations are presented. In 'Heating demand: building simulation' section, heating demand is calculated through building simulations based on statistically defined occupancy patterns
Fig. 5 Difference (\%) on energy consumption between building stock and reference households

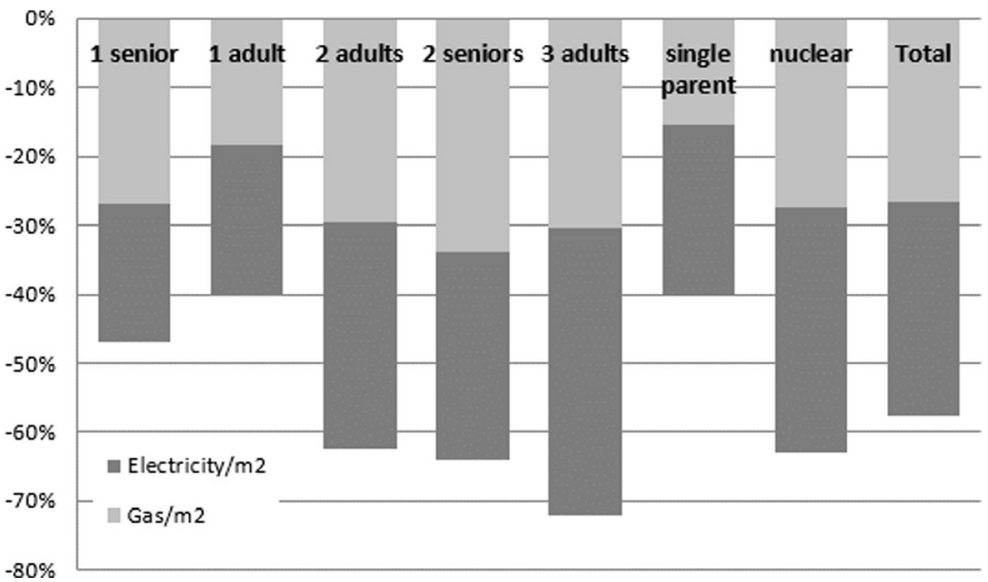




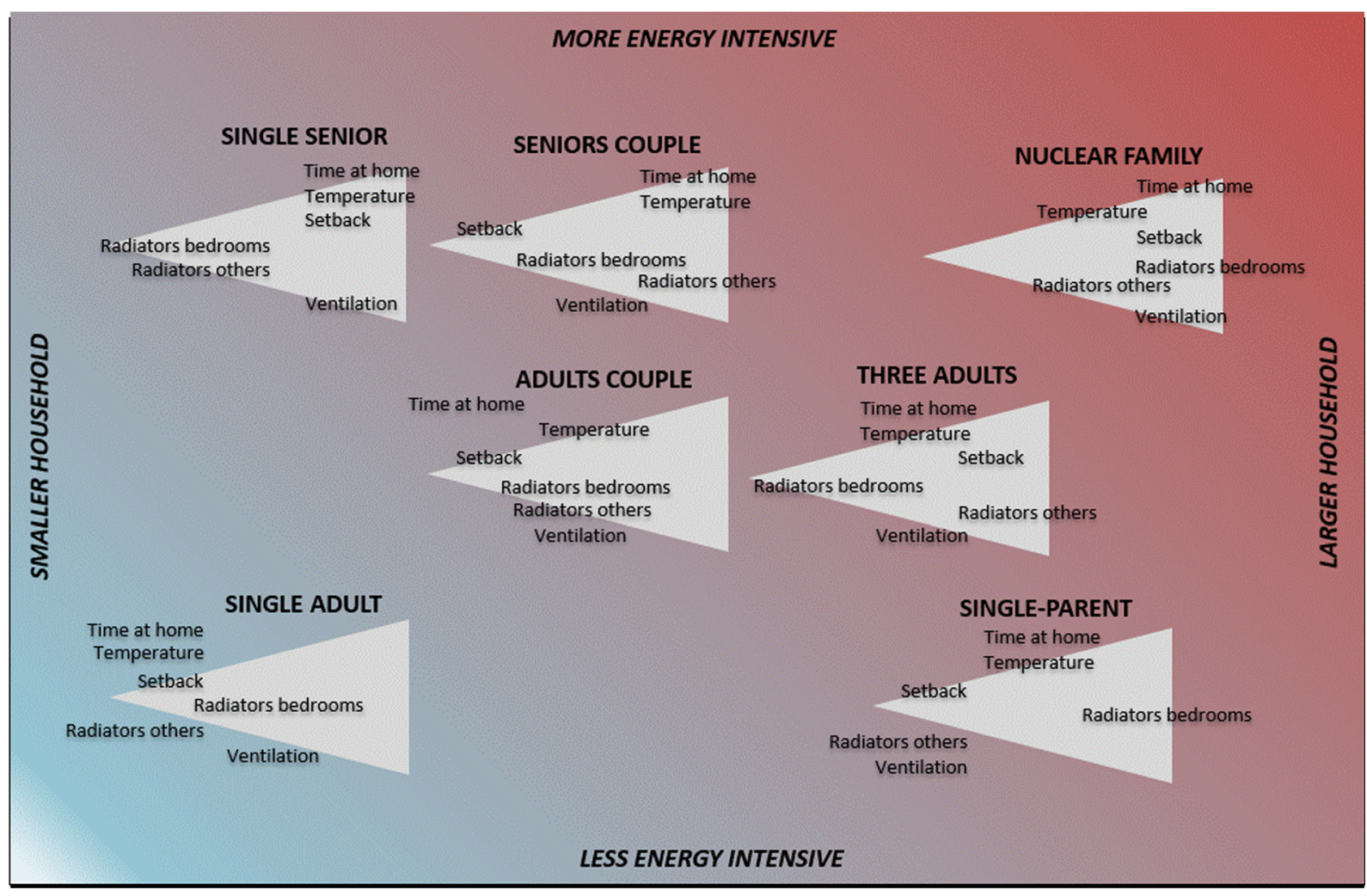

Fig. 6 Household profiles and related energy behaviours

(nationwide Dutch household profiles). In 'Domestic hot water' section, domestic hot water is calculated based on the requirements per person based on Dutch regulations. In 'Electricity consumption' section, electricity demand is calculated based on the statistical occupancy profiles and hours of use of appliances per household type. In 'Energy generation' section, the calculations of energy generation with photovoltaic panels according to different building (roof) characteristics are presented.

Heating demand: building simulation

Building simulations of the 2ndSkin solution were carried out with different household profiles. The hour-tohour dynamic building simulations were performed with Bink software (Bink software, n.d.) for each type of household using two scenarios: a pre-renovation stateof-the-art behaviour scenario based on the statistical analysis of the WoON dataset (Tigchelaar and Leidelmeijer, 2012), and a post-renovation scenario, also based on the statistical analysis but modified to reflect a possible rebound effect and changes in behaviour. The expected changes aimed at reflecting occupants trying to achieve higher levels of comfort, but also reflecting a better control of the heating system (for example by encouraging the use of setback temperatures when absent and during the night). Table 2 shows the building characteristics used as input in the building simulation model.

Each room is modelled as one thermal zone, as we wish to investigate the effect that preferences for room temperatures and spaces heated have on energy demand.

Table 2 Input for building simulation software

\begin{tabular}{ll}
\hline & Specifications \\
\hline Roof & $\mathrm{Rc} 4.5$ \\
Facade elements & $\mathrm{Rc} 6.5$ \\
Ground floor & $\mathrm{Rc} 3.5$ \\
Window frames & $\mathrm{Rc} 0.8$ \\
Double glazing & $\mathrm{U} 0.8(1.135) \mathrm{g}_{\mathrm{g}} \mathrm{o}, 8$ \\
Infiltration & $0.4 \mathrm{dm}^{3} / \mathrm{s}^{2} .^{2}$ \\
Ventilation system & Balanced ventilation efficiency 0.75 \\
Heating system & $24 \mathrm{~kW}$ central heating boiler \\
\hline
\end{tabular}


The heating demand per room was calculated assuming a $100 \%$ efficiency of systems, according to the schedules defined per household profile (intermittent comfort). The system adjusts the temperature of the room according to the comfort requirements, with unlimited capacity. The comfort temperature per room is determined per household type, based on the household profiles (Fig. 6). A summary of the profiles is presented in Table 3.

Natural ventilation is only considered for the summer period, when external temperature reaches $18{ }^{\circ} \mathrm{C}$ or internal temperature exceeds $25^{\circ} \mathrm{C}$. Thus, natural ventilation does not have an effect on heating demand in the simulations.

The internal heat gains are integrated into the simulation model in two ways. Artificial lighting is defined as specific artificial lighting use patterns defined per household type, which are based on the household profiles. Internal heat gains for appliances and electric equipment are calculated based on statistical data on electricity consumption per household type in reference dwellings (WoON dataset). The gains of electricity are evenly distributed over the zones of the dwelling. Table 4 shows the internal heat gains based on electricity consumption per household. The schedules for artificial lighting and occupancy can be found in Guerra-Santin and Silvester (2016).

\section{Pre-renovation behaviour}

Simulations per household type assuming 'pre-renovation' behaviours were carried out. These behaviours were obtained from statistical data in the Netherlands and therefore, reflect current and actual lifestyle and preferences of Dutch households (Fig. 6). Table 5 shows the results for heating demand for the seven household types. In addition, a building simulation with a standardised occupancy was also run. The standardised occupancy considers the thermostat at $16{ }^{\circ} \mathrm{C}$ from 2300 to 0700 hours, at $19{ }^{\circ} \mathrm{C}$ from 0700 to 1700 hours, and at $21^{\circ} \mathrm{C}$ from 1700 to 2300 hours. This standard occupancy profile is currently used in practice.

Figure 7 shows a comparison between the heating demand for different household types and apartment types. The results are shown per type of apartment, since their size and location within the building will have an effect on heating demand. Apartments type A have three bedrooms and a total area of $68 \mathrm{~m}^{2}$, while apartments type B have two bedrooms and a total area of $58 \mathrm{~m}^{2}$ (see Fig. 1).

The results of the simulations showed an up to twofold difference between the heating demand of the standardised profile, and the households with the lowest (single adults) and highest (single seniors) heating demand, highlighting the large overestimation and underestimation of heating demand when using standardised profiles. The results also showed that the heating demand calculated for single adults is $75 \%$ lower than for single seniors, while the heating demand calculated for a couple of adults is $30 \%$ lower than the demand calculated for a couple of seniors. The same difference is seen between single parent households and nuclear families. The difference in heating demand between types of apartments is larger in households with higher heating demand, for example in nuclear families, the difference on heating demand between small apartments in the middle of the building (apartments type B in the first and second floor) and large apartments in the ground or top floors (apartments type A in the ground floor and top floor) can be up to $30 \%$.

Table 3 Summary of household profiles

\begin{tabular}{llllll}
\hline & Presence & Temperature & Setback & Radiators bedroom & Radiators others \\
\hline 1 Senior & More often & Warmer & Wasteful & Semi-open & Semi-open \\
2 Seniors & More often & Warmer & Setback & Semi-open & Open \\
1 Adult & Less often & Cooler & Setback & Semi-open & Closed \\
2 Adults & Less often & Average & Setback & Semi-open & Semi-open \\
3 Adults & Average & Average & Wasteful & Closed & Open \\
Single parent & Average & Average & Setback & Open & Closed \\
Nuclear family & More often & Average & Wasteful & Open & Semi-open \\
\hline
\end{tabular}


Table 4 Internal heat gains based on electricity consumption. Electricity in kilowatt hour/square metre

\begin{tabular}{llllllll}
\hline & \multicolumn{2}{l}{ All buildings } & & \multicolumn{3}{l}{ Reference building } \\
\cline { 2 - 3 } \cline { 7 - 8 } \cline { 7 - 8 } & $N$ & $\mathrm{kWh} / \mathrm{m}^{2}$ & $\mathrm{IHG}$ & & $N$ & $\mathrm{kWh} / \mathrm{m}^{2}$ & $\mathrm{IHG}$ \\
\hline $\mathbf{N}$ & 6648 & 27.1 & 3.1 & 293 & 28.3 & 3.2 \\
$\mathbf{N}$ & 11,429 & 35.5 & 4.0 & 888 & 33.0 & 3.8 \\
$\mathbf{N}$ & 13,056 & 35.0 & 4.0 & 329 & 36.0 & 4.1 \\
$\mathbf{N}$ & 8236 & 33.5 & 3.8 & 192 & 34.8 & 4.0 \\
$\mathbf{N}$ & 3892 & 44.1 & 5.0 & 80 & 38.1 & 4.4 \\
$\mathbf{N}$ & 2202 & 35.3 & 4.0 & 185 & 36.6 & 4.2 \\
$\mathbf{N}$ & 13,021 & 36.2 & 4.1 & 227 & 41.7 & 4.8 \\
Total & 58,484 & 34.9 & 4.0 & 2194 & 34.4 & 3.9 \\
\hline
\end{tabular}

\section{Post-renovation behaviour}

A second set of simulations per household type were carried out assuming a change on behaviour after the renovation. In this scenario, we intend to show the influence that behavioural changes could have if (1) people currently heating to a lower degree, increase the indoor temperature (for example, single adults), and (2) assuming a better control on the heating system, by heating only occupied spaces and using a setback in the thermostat during the night and during absent hours.

Table 6 shows the results of these simulations. In Fig. 8, we show a comparison between both occupancy scenarios per household, also showing the results with the standardised occupancy profile. The figure shows that energy demand decreases greatly for households with seniors (up to $40 \%$ reduction), and decreases slightly for all other households, except for single adults. Single adults were found, in the statistically developed profiles, to under-heat spaces. Assuming that they would heat to higher temperatures to achieve more comfort, the heating demand for this household increases twofold. The lower heating demand of seniors is associated to a better use of thermostat setback. In comparison to the standardised behaviour, single seniors and nuclear families have a higher heating demand, while single adults and couple adults have a lower heating demand.

Domestic hot water

The energy demand for domestic hot water was calculated based on Eq. 1, assuming 5 min showers per person per day, one and a half minutes using the sink per person per day, and using the kitchen sink for $1 \mathrm{~min}$ per household per day. Table 7 shows the results. In addition, a scenario considering the use of a heat recovery shower (www.milieucentraal.nl, 2016) was also calculated. According to specifications, these systems can save up to $100 \mathrm{~m} 3 \mathrm{gas} / \mathrm{year}$ per household (www.milieucentraal.nl, 2016), or 30\% of the energy use. In order to take into account the household size, we use the value of $30 \%$ reduction.

$Q=c X \rho X(\theta w-\theta k) X q_{v} X t$

where:

$Q \quad$ Heat demand in kilojoules

c Specific heat of water in kilojoules/kilogram degree Celsius (4.19)

$\rho \quad$ Mass density cold water in kilogram/litre

$\theta w$ Temperature warm tap water in degree Celsius

$\theta k \quad$ Temperature cold water in degree Celsius

$q v \quad$ Needed flow in litre/second

$t \quad$ Time

\section{Electricity consumption}

The electricity demand for appliances, electric equipment and artificial lighting per household type was calculated based on the statistically developed household profiles (Fig. 6). Two scenarios were used, one with efficient appliances and one with inefficient appliances.

\section{Artificial light}

For the calculation of electricity demand for lighting, we assumed that the lights would be off in sleeping hours (2400-0600 hours), during daylight hours (0900-1800 hours) and when the residents are not at home (defined per household type). It was also assumed that in households of more than two persons, more than one light would be on (Guerra-Santin and Silvester 2016).

\section{Appliances and electric equipment}

We assumed that the use of appliances and electric equipment was defined by the presence of people at 
Table 5 Results building simulation per household type, and type of apartment assuming pre-renovation behaviours. Heating demand $(\mathrm{kWh} /$ year $)$

\begin{tabular}{lllllllll}
\hline & $\begin{array}{l}\text { Single } \\
\text { adult }\end{array}$ & $\begin{array}{l}\text { Single } \\
\text { senior }\end{array}$ & $\begin{array}{l}\text { Adults } \\
\text { couple }\end{array}$ & $\begin{array}{l}\text { Seniors } \\
\text { couple }\end{array}$ & $\begin{array}{l}\text { Three } \\
\text { adults }\end{array}$ & $\begin{array}{l}\text { Single } \\
\text { parent }\end{array}$ & $\begin{array}{l}\text { Nuclear } \\
\text { family }\end{array}$ & $\begin{array}{l}\text { Standard } \\
\text { household }\end{array}$ \\
\hline $\begin{array}{c}\text { A Ground } \\
\text { floor }\end{array}$ & 426 & 2002 & 882 & 1536 & 954 & 1060 & 1625 & 924 \\
A 1st floor & 398 & 1685 & 777 & 1335 & 844 & 803 & 1393 & 801 \\
A 2nd floor & 384 & 1595 & 719 & 1216 & 780 & 872 & 1310 & 751 \\
A 3rd floor & 350 & 1334 & 625 & 1051 & 688 & 644 & 1144 & 641 \\
B Ground & 385 & 1586 & 714 & 1212 & 778 & 866 & 1305 & 746 \\
$\quad \begin{array}{l}\text { floor } \\
\text { B 1st floor }\end{array}$ & 348 & 1318 & 617 & 1039 & 680 & 636 & 1135 & 632 \\
B 2nd floor & 428 & 1864 & 843 & 1429 & 913 & 1018 & 1545 & 868 \\
B 3rd floor & 392 & 1555 & 736 & 1234 & 802 & 759 & 1315 & 746 \\
\hline
\end{tabular}

home (Guerra-Santin and Silvester 2016). For example, a household type absent during three evenings per week was consider to only use entertainment equipment during four evenings per week.

The appliances and electric equipment were categorised according to their use: (1) all day appliances such as WIFI router, refrigerator, freezer and alarm clocks; (2) short-use cooking appliances such as coffee machine, water boiler, microwave oven, toaster and kettle; (3) long-use cooking appliances such as oven, stove and cooking hood; (4) cleaning appliances such as washing machine, drying machine, dishwasher, iron and vacuum cleaner; (5) entertainment equipment such as TVs and game consoles, and (6) office equipment such as desktops, laptops, monitors and printers.

The assumptions on the hours of use are shown in Table 8, based on (www.energuide.be, 2016). We only considered the use of a limited number of appliances and electric equipment to reflect the socio-economical status of the household living in the reference building. A distinction was made between efficient appliances and inefficient appliances for a selection of items: fridge/freezer, washing machine, computers, TVs and light bulbs.

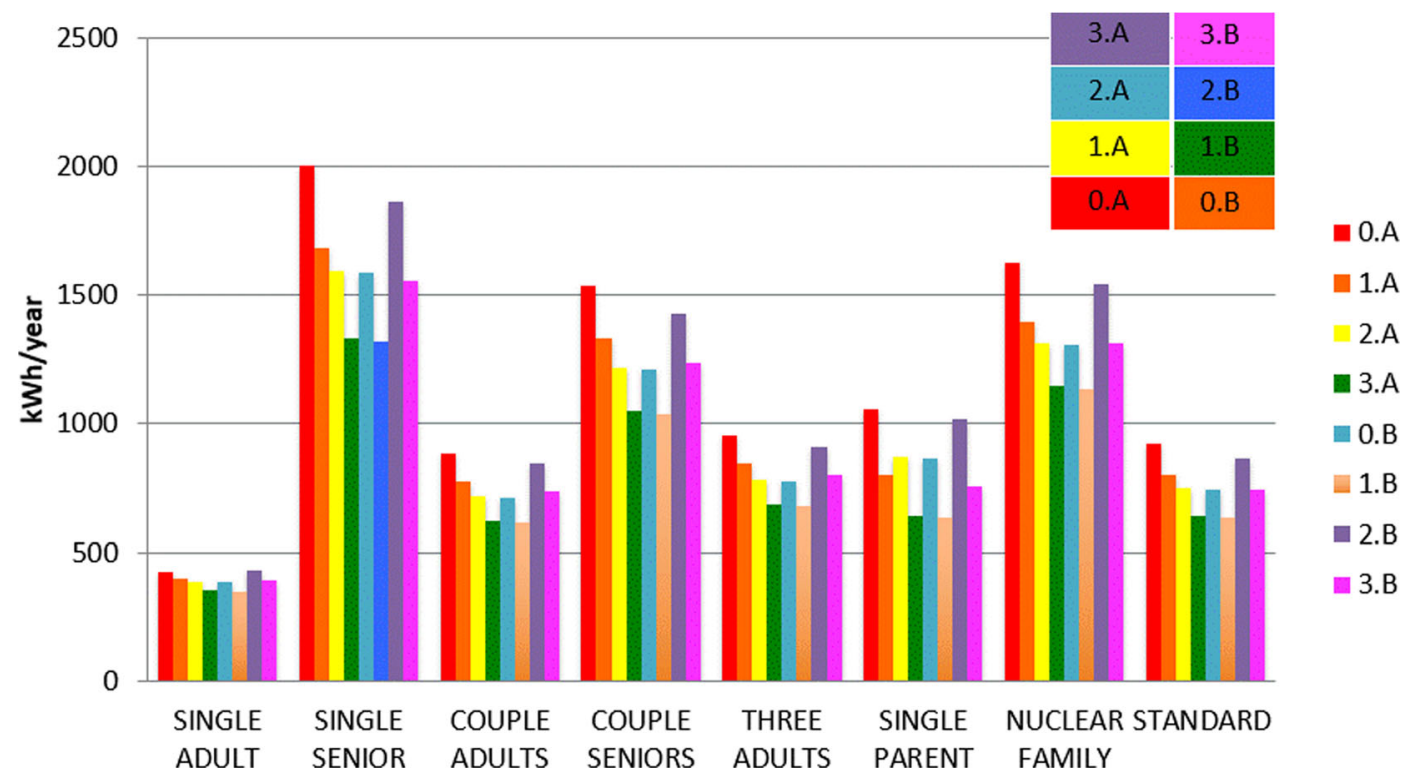

Fig. 7 Heating demand per household type, per apartment type, assuming pre-renovation behaviour 
Table 6 Results building simulation per household type, and type of apartment assuming post-renovation. Heating demand (kWh/year)

\begin{tabular}{llllllll}
\hline & Single adult & Single senior & Adults couple & Seniors couple & Single parent & Nuclear family & Single parent \\
\hline A Ground floor & 821 & 1103 & 679 & 937 & 864 & 1048 & 1587 \\
A 1st floor & 772 & 1080 & 609 & 854 & 785 & 763 & 1330 \\
A 2nd floor & 704 & 1019 & 567 & 796 & 727 & 861 & 1335 \\
A 3rd floor & 649 & 914 & 502 & 718 & 653 & 609 & 1109 \\
B Ground floor & 735 & 1018 & 565 & 793 & 718 & 854 & 1328 \\
B 1st floor & 643 & 902 & 495 & 708 & 643 & 601 & 1099 \\
B 2nd floor & 845 & 1145 & 658 & 901 & 836 & 749 & 720 \\
B 3rd floor & 743 & 1027 & 584 & 810 & & 1518 \\
\hline
\end{tabular}

Standby setting of appliances was not considered in any of the scenarios, since this is considered to be a bad practice that the 2 ndSkin project also aims to reduce. This is however, out of the scope of this paper.

Table 9 shows the results per household type for both electricity scenarios: efficient appliances and inefficient appliances. The results showed the large difference between electricity demand between singles and families. A twofold difference can be seen between nuclear families and singles (efficient appliances). The calculations showed similarities to average electricity consumption based on statistical data from the WoON dataset (Table 9). The mean electricity consumption in reference buildings is, on average, between the calculations with inefficient and efficient appliances (Figs. 8 and 9). However, in relation to the reference building, we seem to be underestimating the electricity consumption of young households and senior couples.

The energy demand for the heat recovery balanced ventilation system is assumed to be the same for all household types, and it is based on Blom (2010).
Energy generation

Energy generation was calculated for five scenarios, taking into account the orientation of the building, the type of roof and the possibility to provide an attic for installations. The five scenarios are as follows: NorthSouth orientation with flat roof, North-South orientation with pitched roof, North-West orientation with flat roof with an attic for installations, East-West orientation with flat roof, and East-West orientation with pitched roof.

Calculations were made assuming the use of a CSun255-60P solar panel (www.csun-solar.comepb, 2016). Each module has a capacity of $255 \mathrm{Wp}$. Results of the calculations are shown in Table 10. The energy generated in the roof of the building is divided by the number of apartments in the buildings. Porch apartment buildings can have either three or four floors. Given that the 2ndSkin renovation strategy could be applied to both possibilities, we studied the results of the calculations considering both scenarios. The energy generated per apartment can be seen in the right-side columns of
Fig. 8 Heating demand per household type, per apartment type. Comparison between prerenovation and post-renovation behaviours

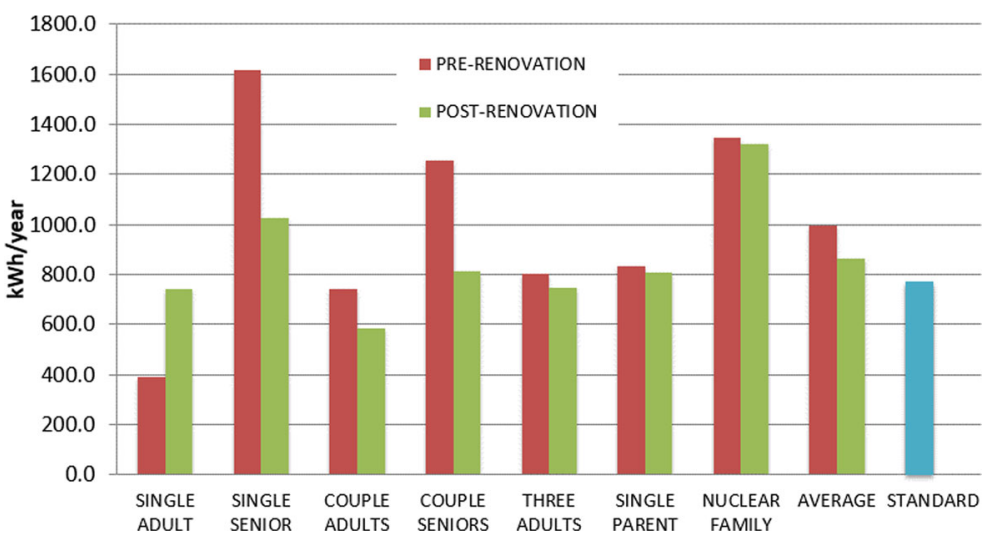


Table 7 Calculated energy demand per household based on requirements per person

$\begin{array}{ll}\begin{array}{l}\text { Energy for domestic } \\ \text { hot water per }\end{array} & \text { Energy for domestic } \\ \text { year (kWh/year) } & \text { incl. estimated savings } \\ & (\mathrm{kWh} / \text { year })\end{array}$

\begin{tabular}{lll}
\hline Single adult & 726.29 & 508.403 \\
Single senior & 726.29 & 508.403 \\
Adult couple & 1155.81 & 809.07 \\
Senior couple & 1155.81 & 809.07 \\
Three adults & 1680.84 & 1176.59 \\
Single parent & 1680.84 & 1176.59 \\
Nuclear family & 2205.87 & 1544.11 \\
\hline
\end{tabular}

Table 10. Figure 10 shows the results graphically. The results showed that the worst case scenario is the fourstorey building with pitched roof and North-South orientation, while the best case scenario is the threestorey building with East-West orientation. For both, three-storey and four-storey scenarios, the provision of an attic for photovoltaic panels significantly increases the energy generation.

\section{Total energy performance: integration of energy calculations and building simulations}

In this section, we integrate the results of the building simulations with the calculation of electricity demand and renewable energy generation. Table 11 shows the energy requirements per household type for both behaviour scenarios (pre-renovation and post-renovation); both electricity scenarios (efficient and inefficient devices); for both domestic hot water scenarios: (with and without heat recovery); and for the heat recovery bal-
Table 8 Hours of use per appliances and electric equipment [31]

\begin{tabular}{|c|c|c|}
\hline \multirow{4}{*}{$\begin{array}{l}\text { All day } \\
\text { appliances }\end{array}$} & Fridge & \multirow[t]{4}{*}{$24 \mathrm{~h}$ per day $/ 52$ weeks per year } \\
\hline & Freezer & \\
\hline & WIFI router & \\
\hline & $\begin{array}{l}\text { Radio / alarm clock } \\
\text { Mobile phones }\end{array}$ & \\
\hline Sort-use cooking & Coffee machine & $10 \mathrm{~min}$ per day $/ 50$ weeks per year \\
\hline appliances & Microwave oven & \\
\hline & Toaster & \\
\hline & Kettle & \\
\hline Log-use cooking & Cooking hood & 30 min per day $/ 50$ weeks per year \\
\hline appliances & Stove & \\
\hline & Oven & \\
\hline Cleaning & Clothes dryer & 30 min per person per week/50 weeks per year \\
\hline appliances & Dishwasher & \\
\hline & Iron & \\
\hline $\begin{array}{l}\text { Cleaning } \\
\text { appliances }\end{array}$ & Washing machine & $\begin{array}{l}\text { One cycle per person per week/50 weeks per } \\
\text { year }\end{array}$ \\
\hline $\begin{array}{l}\text { Entertainment } \\
\text { equipment }\end{array}$ & TV & $\begin{array}{l}\text { Equipment on when residents at home during } \\
\text { evenings (adults and families with children) or } \\
\text { during all day (seniors) } / 50 \text { weeks per year }\end{array}$ \\
\hline $\begin{array}{l}\text { Entertainment } \\
\text { equipment }\end{array}$ & $\begin{array}{l}\text { Game console } \\
\text { (households with } \\
\text { children) }\end{array}$ & $\begin{array}{l}\text { One hour per day (only households with } \\
\text { children)/ } \\
50 \text { weeks per year }\end{array}$ \\
\hline Office equipment & $\begin{array}{l}\text { Desktop and monitor } \\
\text { Laptop }\end{array}$ & $\begin{array}{l}\text { Equipment on when residents at home during } \\
\text { mornings } \\
\text { and afternoons (only adults and families with } \\
\text { children)/ } \\
50 \text { weeks per year }\end{array}$ \\
\hline Office equipment & Printer & $\begin{array}{l}\text { One hour per week (only adults and families with } \\
\text { children)/50 weeks per year }\end{array}$ \\
\hline
\end{tabular}


Table 9 Results electricity calculations and statistical data from WoON survey in kilowatt hour/year

\begin{tabular}{lllll}
\hline & Efficient appliances & Inefficient appliances & WoON all buildings & WoON reference building \\
\hline Single adult & 1048.5 & 2062.9 & 2341.3 & 1837.3 \\
Single senior & 1087.7 & 2332.6 & 2162.2 & 1724.2 \\
Adults couple & 1629.5 & 2755.5 & 3479.4 & 2338.4 \\
Seniors couple & 1395.3 & 2737.7 & 3358.3 & 2342.3 \\
Three adults & 1958.8 & 3222.0 & 4681.2 & 2725.8 \\
Nuclear family & 1954.1 & 3229.9 & 3193.9 & 2405.3 \\
Single parent & 2301.1 & 3687.6 & 4309.1 & 2772.9 \\
Average & 1625.0 & 2861.2 & 3341.4 & 2118.6 \\
\hline
\end{tabular}

anced ventilation system.

Figure 11 shows a comparison between the energy (gas and electricity) consumed in the reference dwellings (based on WoON statistical data shown in Table 1), and calculated energy demand (for heating, domestic hot water and electricity) based on two scenarios: (1) inefficient appliances and behaviour, and (2) efficient appliances and behaviour. Inefficient appliances and behaviours is based on the electricity demand calculated using the energy consumption of inefficient appliances, and the pre-renovation behaviour defined in 'Pre-renovation behaviour' section. Efficient appliances and behaviours is based on the electricity demand calculated using the energy consumption of efficient appliances, and the post-renovation behaviour defined in section 'Post=renovation behaviour'. The figure shows that the energy demand of the 2ndSkin technical solution excluding energy generation (i.e. only renovation without behavioural change or purchasing of more efficient appliances) is reduced by 59\%. If we also consider the scenario with efficient appliances and improved control and behaviour, we reach a reduction on energy demand of $71 \%$.

Figure 11 also shows the energy demand for heating (simulated in Bink), domestic hot water (estimated) and electricity (calculated based on appliances power and hours of use) per household type in the two scenarios mentioned before. The dashed lines in the figure correspond to the best case and worst case scenarios for energy generation identified in 'Energy generation' section (Fig. 12). The figure shows that only the scenario in which the provision of an attic structure is envisioned to

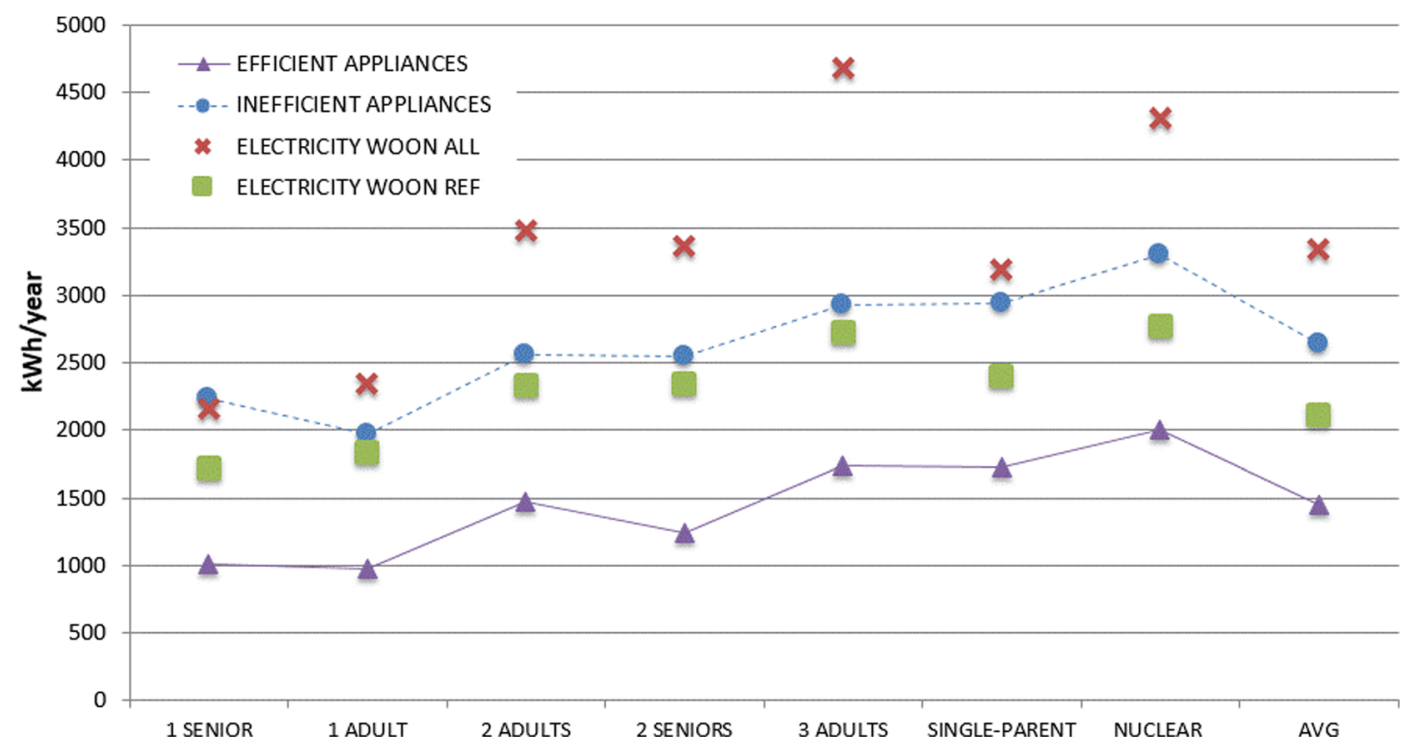

Fig. 9 Comparison electricity calculation and WoON statistics per household 
Table 10 Energy generation per building orientation and type of roof

\begin{tabular}{|c|c|c|c|c|c|c|c|c|}
\hline & \multirow[t]{2}{*}{ Orientation } & \multirow{2}{*}{$\begin{array}{l}\text { Type of } \\
\text { roof }\end{array}$} & \multirow{2}{*}{$\begin{array}{l}\text { Number of } \\
\text { modules }\end{array}$} & \multirow{2}{*}{$\begin{array}{l}\text { Panels } \\
\text { installed } \\
\mathrm{m}^{2}\end{array}$} & \multirow{2}{*}{$\begin{array}{l}\text { Installed } \\
\text { capacity } \\
(\mathrm{kWp})\end{array}$} & \multicolumn{3}{|c|}{ Production (kWh/year) } \\
\hline & & & & & & $\begin{array}{l}\text { One porch } \\
\text { building }\end{array}$ & $\begin{array}{l}\text { Per unit ( } 6 \text { per } \\
\text { porch) }\end{array}$ & $\begin{array}{l}\text { Per unit ( } 8 \text { per } \\
\text { porch) }\end{array}$ \\
\hline EW_flat & East-west & Flat roof & 52 & 84.4 & 13.26 & $10,430.5$ & 1738.4 & 1303.8 \\
\hline NS_flat & North-south & Flat roof & 36 & 58.4 & 9.18 & 7795 & 1299.2 & 974.4 \\
\hline NS_flat_b & North-south & $\begin{array}{l}\text { Flat roof } \\
\text { (attic) }\end{array}$ & 90 & 146.1 & 22.95 & $19,544.5$ & 3257.4 & 2443.1 \\
\hline EW_pitch & East-west & $\begin{array}{l}\text { Pitched } \\
\text { roof }\end{array}$ & 52 & 84.4 & 13.26 & $* 10430.5$ & 1738.4 & 1303.8 \\
\hline NS_pitch & North-south & $\begin{array}{c}\text { Pitched } \\
\text { roof }\end{array}$ & 26 & 42.2 & 6.63 & *5215.3 & 869.2 & 651.9 \\
\hline
\end{tabular}

support the photovoltaic panels, the energy generated covers the energy demand when domestic hot water and electricity are considered (using the efficient scenario). If we consider the inefficient scenario, the energy generated covers half of the demand. In all other roof scenarios, the energy generated only covers the heating demand in the best case scenario. Table 12 shows the additional area of photovoltaic panels necessary to reach the zero energy target for each of the porch-buildings roof scenarios.
Therefore, extra surface of photovoltaic panels would be necessary to achieve the zero-on-themeter solution only with photovoltaic panels. The provision of PV panels on façade surfaces could potentially be used to cover the rest of the energy generation required. However, this possibility would also depend on the orientation of the building. Table 13 shows the energy generation based on wall surface area. The results show that the energy demand can only be met with the provision of an attic
Fig. 10 Photovoltaic panels energy generation for difference building scenarios

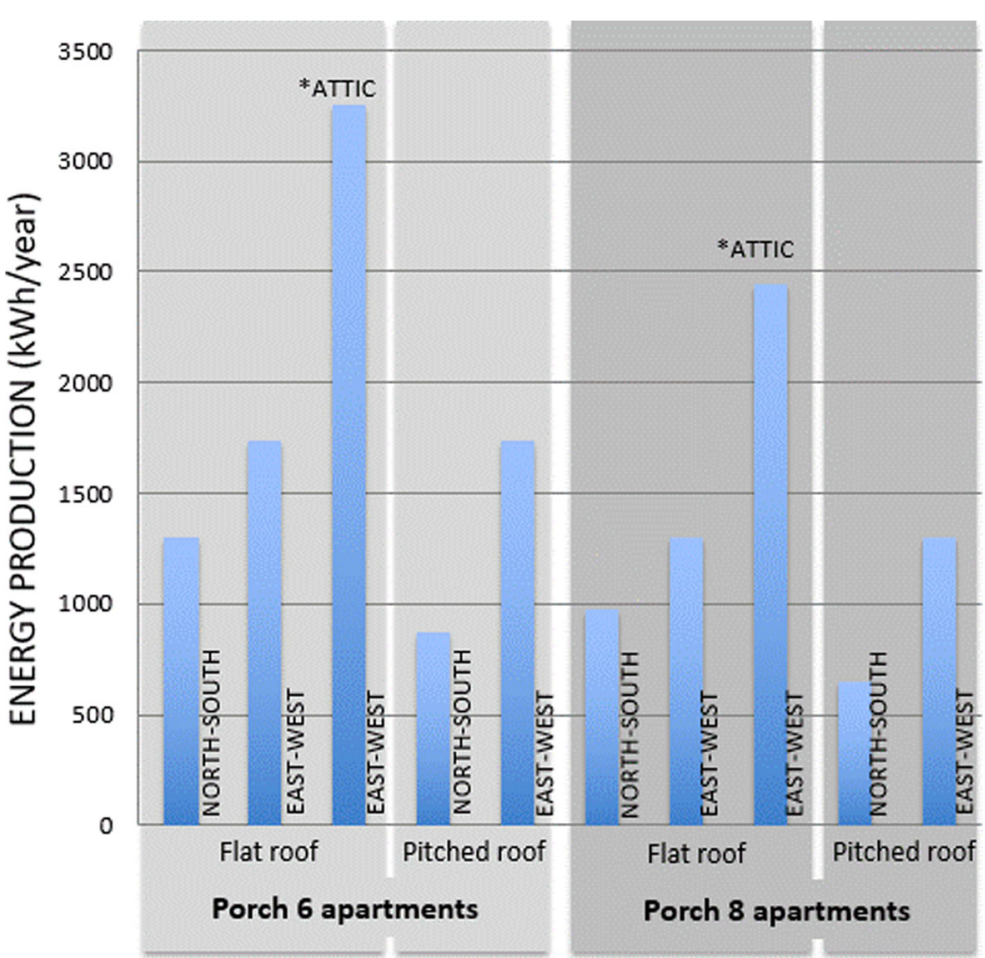


Table 11 Energy demand per household type (average apartment) in kilowatt hour/year

\begin{tabular}{|c|c|c|c|c|c|c|c|}
\hline & $\begin{array}{l}\text { Heating demand } \\
\text { pre-renovation }\end{array}$ & $\begin{array}{l}\text { Heating demand } \\
\text { post-renovation }\end{array}$ & $\begin{array}{l}\text { Efficient } \\
\text { appliances }\end{array}$ & $\begin{array}{l}\text { Inefficient } \\
\text { appliances }\end{array}$ & $\begin{array}{l}\text { Domestic } \\
\text { hot water }\end{array}$ & $\begin{array}{l}\text { Domestic hot water incl. } \\
\text { estimated savings }\end{array}$ & $\begin{array}{l}\text { Balance } \\
\text { ventilation }\end{array}$ \\
\hline $\begin{array}{l}\text { Single } \\
\text { adult }\end{array}$ & 388.9 & 739.0 & 1048.5 & 2062.9 & 726.29 & 508.403 & 723 \\
\hline $\begin{array}{l}\text { Single } \\
\text { senior }\end{array}$ & 1617.4 & 1026.0 & 1087.7 & 2332.6 & 726.29 & 508.403 & 723 \\
\hline $\begin{array}{l}\text { Adults } \\
\text { couple }\end{array}$ & 739.1 & 582.4 & 1629.5 & 2755.5 & 1155.81 & 809.07 & 723 \\
\hline $\begin{array}{l}\text { Seniors } \\
\text { couple }\end{array}$ & 1256.5 & 814.6 & 1395.3 & 2737.7 & 1155.81 & 809.07 & 723 \\
\hline $\begin{array}{l}\text { Three } \\
\text { adults }\end{array}$ & 804.9 & 746.9 & 1958.8 & 3222.0 & 1680.84 & 1176.59 & 723 \\
\hline $\begin{array}{l}\text { Nuclear } \\
\text { family }\end{array}$ & 832.3 & 807.5 & 1954.1 & 3229.9 & 1680.84 & 1176.59 & 723 \\
\hline $\begin{array}{l}\text { Single } \\
\text { parent }\end{array}$ & 1346.5 & 1320.8 & 2301.1 & 3687.6 & 2205.87 & 1544.11 & 723 \\
\hline Average & 997.9 & 862.5 & 1625.0 & 2861.2 & 1333.11 & 933.18 & 723 \\
\hline
\end{tabular}

(north-south orientation) on up to three levels porch buildings. For an east-west orientation, the total energy demand can be almost met with the energy production on-site for buildings with three levels (six housing units). To cover the energy demand of north-south orientations without attic provision, and porch buildings with four levels, an extra surface of $12-20 \mathrm{~m}^{2}$ of panels is needed.

\section{Discussion}

Before the renovation of a building, occupancy monitoring could be used to investigate the actual building control practices and occupants' behaviour, preferences and requirements (Guerra-Santin and Tweed 2015a, b). The information could be used as input in building simulation to determine more accurately the energy

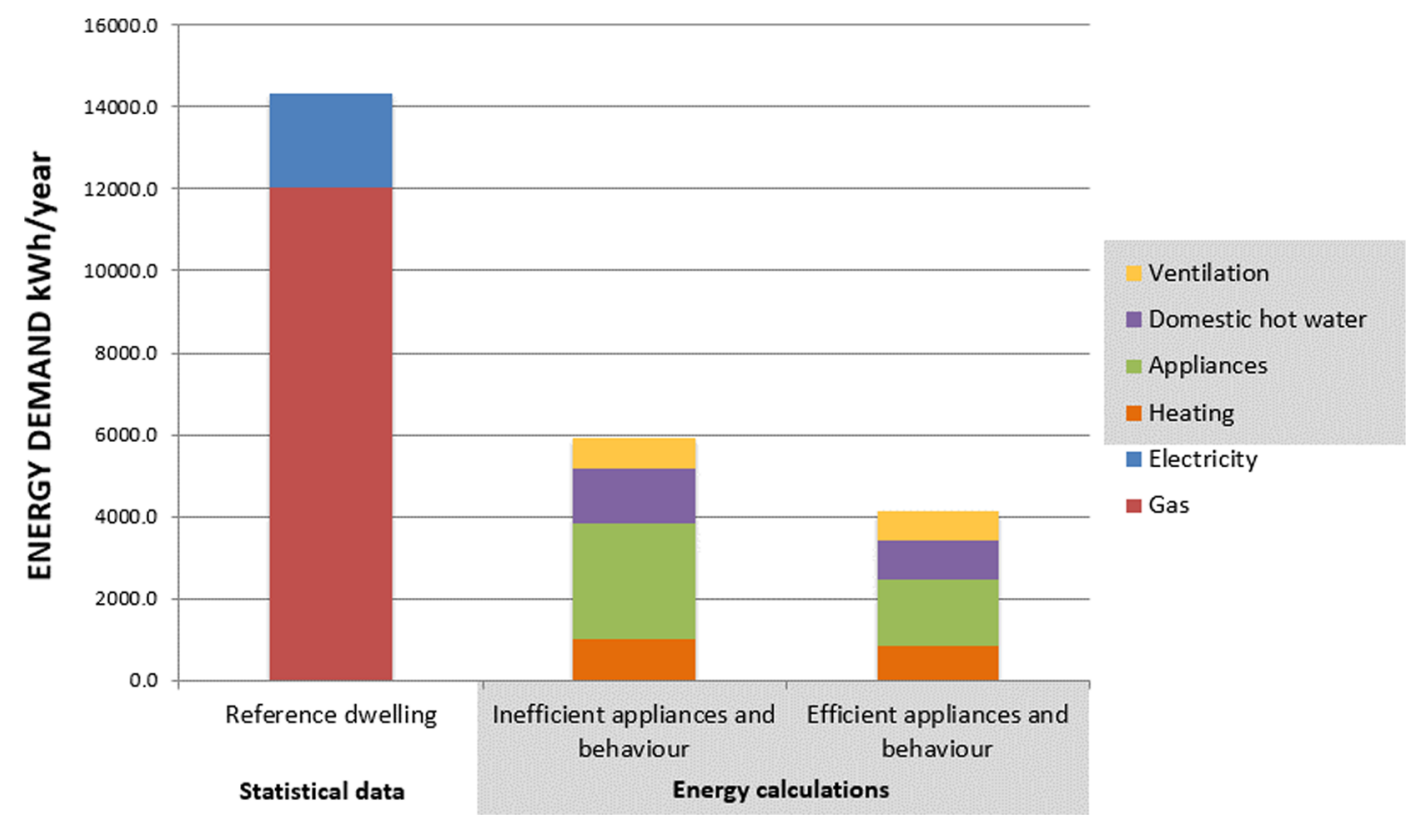

Fig. 11 Energy demand calculated based on inefficient and efficient appliances and behaviours in comparison to the statistical energy consumption in reference dwellings 
Fig. 12 Energy demand for efficient and inefficient scenarios in comparison to best case and worst case energy generation scenarios

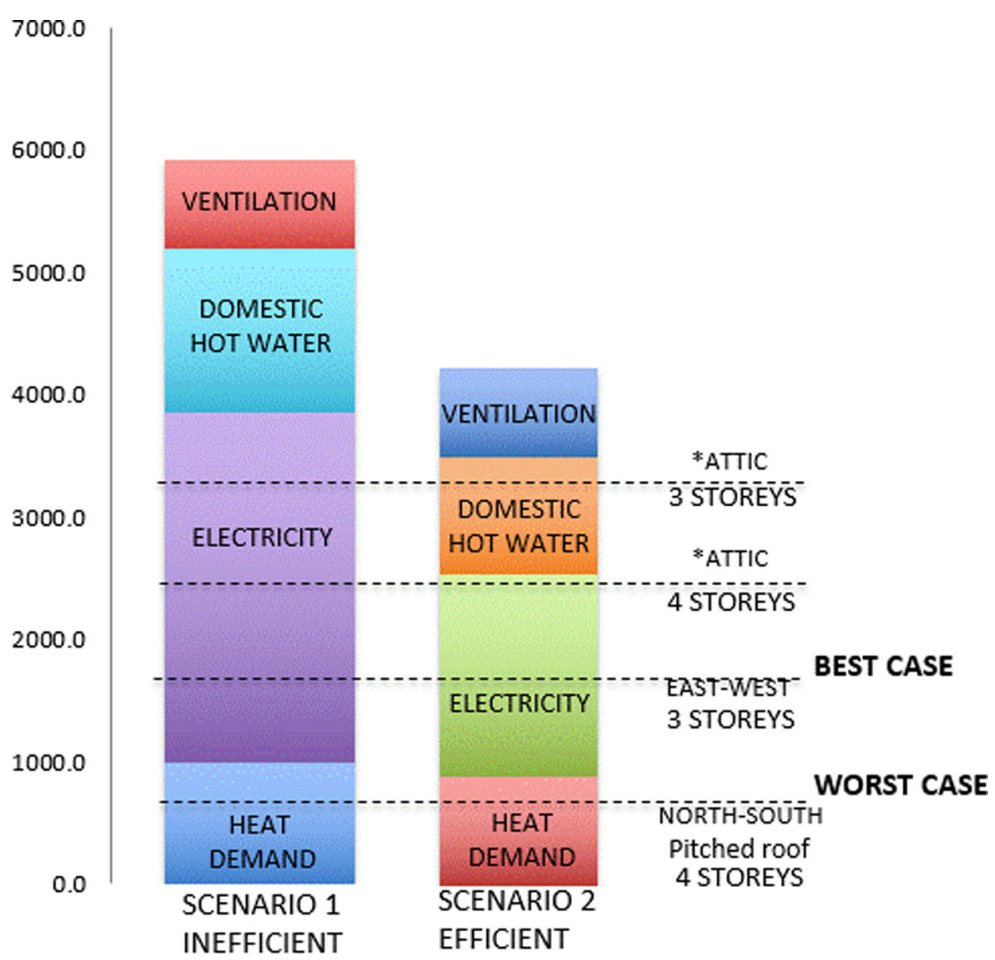

ENERGY DEMAND (kWh/year)

ENERGY PRODUCTION (kWh/year) demand of each household. However, in practice there are limitations on the occupancy investigation based on actual project times (time available to carry out prerenovation investigations), resources to monitor and analyse data collected (time, money and expertise), accessibility to the dwellings (not all resident will be willing or able to be monitored), and scale of the monitoring (not all dwellings can be monitored, just a sample). Therefore, the use of the data on actual occupancy patterns and actual occupant behaviour will be limited to its availability. To overcome these limitations, we have defined within the 2ndSkin approach statistically defined occupancy patterns based on a national Dutch sample. These profiles can be alternatively used in building simulations to calculate the energy demand when monitoring is not possible, or in very early stages of the project. In addition, for landlords on long-term investments and local governments on zero energy cities, it would be important to calculate the energy savings with the Dutch household profiles, because on average, households in social housing estates move on cycles of 7 years. However, when data from building monitoring

Table 12 Required surface of PV panels to cover average demand, per building/roof scenario

\begin{tabular}{|c|c|c|c|c|c|c|}
\hline \multirow[b]{2}{*}{ Scenario } & \multicolumn{2}{|c|}{ Production (kWh/year) } & \multicolumn{2}{|c|}{ Energy gap (kWh/year) } & \multicolumn{2}{|c|}{ Surface needed $\left(\mathrm{m}^{2}\right)$} \\
\hline & $\begin{array}{l}\text { Per unit } \\
\text { ( } 6 \text { per porch) }\end{array}$ & $\begin{array}{l}\text { Per unit } \\
\text { (8 per porch) }\end{array}$ & $\begin{array}{l}\text { Per unit } \\
\text { ( } 6 \text { per porch) }\end{array}$ & $\begin{array}{l}\text { Per unit } \\
\text { ( } 8 \text { per porch) }\end{array}$ & $\begin{array}{l}\text { Per unit } \\
\text { ( } 6 \text { per porch) }\end{array}$ & $\begin{array}{l}\text { Per unit } \\
\text { ( } 8 \text { per porch) }\end{array}$ \\
\hline EW_flat & 1738.4 & 1303.8 & 2405.23 & 2839.83 & 19.48 & 23.00 \\
\hline NS_flat & 1299.2 & 974.4 & 2844.43 & 3169.23 & 21.30 & 23.73 \\
\hline NS_flat_b & 3257.4 & 2443.1 & 886.23 & 1700.53 & 6.64 & 12.73 \\
\hline EW_pitch & 1738.4 & 1303.8 & 2405.23 & 2839.83 & 19.48 & 23.00 \\
\hline NS_pitch & 869.2 & 651.9 & 3274.43 & 3491.73 & 24.52 & 26.15 \\
\hline
\end{tabular}


Table 13 Total energy production and surplus energy (in bold) per building/roof scenario

\begin{tabular}{|c|c|c|c|c|c|c|}
\hline \multirow[b]{2}{*}{ Scenario } & \multicolumn{2}{|c|}{ Energy produced in walls surfaces $(\mathrm{kWh} /$ year $)$} & \multicolumn{2}{|c|}{$\begin{array}{l}\text { Total energy (kWh/year) } \\
\text { Walls and roof }\end{array}$} & \multicolumn{2}{|c|}{ Energy gap (kWh/year) } \\
\hline & $\begin{array}{l}\text { Per unit } \\
\text { (6 per porch) }\end{array}$ & $\begin{array}{l}\text { Per unit } \\
\text { (8 per porch) }\end{array}$ & $\begin{array}{l}\text { Per unit } \\
\text { ( } 6 \text { per porch) }\end{array}$ & $\begin{array}{l}\text { Per unit } \\
\text { (8 per porch) }\end{array}$ & $\begin{array}{l}\text { Per unit } \\
\text { (6 per porch) }\end{array}$ & $\begin{array}{l}\text { Per unit } \\
\text { (8 per porch) }\end{array}$ \\
\hline EW_flat & 814.97 & 611.23 & 2553.37 & 1915.03 & 175.17 & 609.77 \\
\hline NS_flat & 440.67 & 136.01 & 1739.87 & 1110.41 & 1638.61 & 1963.41 \\
\hline NS_flat_b & 440.67 & 136.01 & 3698.07 & 2579.11 & -319.59 & 494.71 \\
\hline EW_pitch & 814.97 & 611.23 & 2553.37 & 1915.03 & 175.17 & 609.77 \\
\hline NS_pitch & 440.67 & 136.01 & 1309.87 & 787.91 & 2068.61 & 2285.91 \\
\hline
\end{tabular}

is available, building simulations could provide more accurate heating demand per household.

In this paper, household profiles have been used to calculate the energy demand on the reference building, which is the basis for the 2ndSkin approach. This approach will allow to make design decisions related to the sizing of installations.

The results showed that the roof surface, calculated for different orientation and roof scenarios, was not sufficient to provide with enough PV panels to cover the energy demand. The provision of an attic above the existing roof (or instead of the existing roof) could provide the area required to cover the energy demand. The use of facades to install extra panels could also help to increase the surface available for panels; however, their suitability to generate electricity would also depend on the orientation of the building, and the existence of shading elements on-site. Buildings with a north-south orientation cannot provide sufficient façade surface to cover the demand, except if an attic is provided in the roof. For east-west orientated buildings, the facades can provide enough surface for energy generation. A simple payback analysis, in which the initial investment for the technical solution required for the renovation was compared against the potential energy savings as calculated in this paper, showed that the 2ndSkin renovation would have a payback time of just over 25 years, or a simple average rate of return of $4 \%$ per year. For this payback analysis, we considered the best case scenario as defined in 'Total energy performance: integration of energy calculations and building simulation' section. For the detailed feasibility analysis, see Konstantinou et al. (2017). The feasibility of the zero-on-the-meter approach in the reference building could be increased in projects in which a large number of porch buildings would be renovated, since the surplus of energy generated in east-west orientated buildings could make up for the rest of the demand in north-south buildings. However, given the large differences caused by roof type and orientation, it would be more feasible to integrate, into the 2ndSkin solution, the use of a different type of energy-generating technology. However, this would depend on the number of units to be refurbished and the site characteristics, as well as on the renewable energy available on site, if we wish to comply with the zero-onthe-meter (NOM) concept.

Although out of the scope of this paper, the 2ndSkin approach considers also the provision of smart control and feedback devices in the renovated dwellings as a solution towards better management of energy consumption, and occupants' behavioural change. These solutions might help to further reduce energy consumption after renovation, specially for domestic hot water and electricity consumption, which are the major contributors to energy demand after the renovation. Further research will be aimed at investigating the impact of these measures on the energy demand.

In the scope of the zero-on-the-meter Dutch approach, the use of off-site energy generation would disqualify the 2ndSkin solution as a NOM solution, which would also imply that the housing association would not be able to ask tenants for a financial compensation (under Dutch regulations). However, the off-site generation of renewable energy could potentially decrease the initial investment costs of housing associations, or could decrease the uncertainties related to return of investments. Alternative solutions for the provision of renewable energy on and off-site within the 2ndSkin technical solution will be further investigated. 


\section{Conclusions}

The 2ndSkin project consists on the development of a renovation solution that takes into account the influence of occupants in the building performance with the objective of decreasing uncertainties related to energy savings and return of investments. This user-centred research aimed at investigating the uncertainty that can be encountered before and after the renovation, by comparing the energy demand of different household types based on statistical analysis and building simulations. This paper presented the results of the calculations and analysis made to evaluate the zero energy concept in the 2ndSkin project based on a reference building.

The results of the statistical analysis showed that households living in reference buildings (multi-family rental dwellings of up to five stages) tend to use from 40 to $70 \%$ less energy depending on the household type, than households living in all sort of buildings. These results highlight the importance of using suitable data when calculating the expected energy savings of a renovation.

Furthermore, the analysis showed that, although there are significant differences on the energy use between household types in both the reference building and the total building stock, the differences between household in the reference building are lower. This indicated that occupant behaviour might have a smaller impact on energy use in reference buildings.

The energy simulations to calculate the heating demand per household showed that the highest heating demand is for single seniors households, followed by nuclear families and senior couples. The lowest heating demand was calculated for single adults, followed by adult couples. The analysis also showed that single senior household has a heating demand more than four times higher than the demand of single adults.

When considering scenarios based on behaviour after renovation (considering better control and possible rebound effects), the difference between the lowest and the highest heating demand is reduced to $34 \%$. The post-renovation scenarios consider that single adults would heat more frequently and to a higher degree to provide a comfortable environment, and that households with seniors and adults couples would have better control of the heating system (e.g. they will use a lower setback temperature).
The research showed large statistically significant differences on energy consumption between the different household types, which could contribute to pre-bound effects if these differences are not considered when calculating energy savings and return of investments. Although, in average, the housing associations would break even given the variety of households within one neighbourhood, the increased rent could impact the discretionary income of the tenants (income after deduction of taxes and basic living expenses).

The calculations on the total energy demand showed that the 2ndSkin solution (excluding the energy generated) could decrease the energy consumption by $59 \%$ in a scenario in which prerenovation behaviours and inefficient appliances are considered. This reduction reaches $71 \%$ when a scenario considering a post-renovation scenario and efficient appliances. However, the generation of renewable energy in the roof and façade surface covers only partially the total energy demand, even on the best case scenarios, and so, the use of other energy generation technologies, such as geothermal energy, within the 2 ndSkin renovation strategy should be further investigated.

The analysis of diverse scenarios showed that after minimising the energy demand throughout the envelope and building services upgrade, the most important aspect for the success of the 2ndSkin NOM strategy depends on the orientation and area of the roof, and the number of levels per porch building. In the calculations, we showed that in a worst case scenario with north-south orientation, pitched roof and eight apartments porch building, only $16 \%$ of the energy demand can be covered. In the best case scenario, in which the roof is either covered or substituted for an attic, the energy production can cover $79 \%$ of the demand for a six apartment porch building. The attic solutions proved to be the best solution to provide with the energy demand; however, the suitability of the installation of an attic in the building will depend on the structural integrity of the building, the load of the structure or the capacity (physical and financial) to built a new foundation for the roof and facades.

To conclude, regarding the 2ndSkin technical solution, it is important to add that even without the integration of PV panels to the technical solution, a significant reduction on energy demand can be achieved. 
Open Access This article is distributed under the terms of the Creative Commons Attribution 4.0 International License (http:// creativecommons.org/licenses/by/4.0/), which permits unrestricted use, distribution, and reproduction in any medium, provided you give appropriate credit to the original author(s) and the source, provide a link to the Creative Commons license, and indicate if changes were made.

\section{References}

www.csun-solar.comepb, last accessed June 2016.

www.energuide.be, last accessed June 2016.

www.milieucentraal.nl, accessed June 2016.

http://ec.europa.eu/energy last accessed June 2016.

AgentschapNL (2013). Infoblad Trias Energetica en energieneutraal bouwen. In A. M. v. E. Zaken (Ed.), Utrecht. https://www.rvo.nl/sites/default/files/Infoblad Trias Energetica en energieneutraal bouwen-juni 2013.pdf. Accessed 7 Nov 2016.

Beillan, V., Battaglini, E., Huber, A., Mayer, I., Goater, A., Trotignon, R. (2011). Barriers and drivers to energyefficient renovation in the residential sector. Empirical findings from five European countries, in ECEEE, Summer Study Proceedings, 2011, pp. 1083-1093.

Bell, M., Wingfield, J., Miles-Shenton, D., \& Seavers, J. (2010). Low carbon housing: lessons from Elm Tree Mews. York: Joseph Rowntree Foundation.

Bink software from http://binksoftware.nl

Blom, I. (2010). Environmental impacts during the operational phase of residential buildings. Delft: IOS Press.

Danielski, I. (2012). Large variations in specific final energy use in Swedish apartment buildings: causes and solutions. Energy and Buildings, 49, 276-285. https://doi.org/10.1016/j. enbuild.2012.02.015.

Doran, S. (2005). Improving the thermal performance of buildings in practice. BRE client report no. 78132, for the office of the deputy Prime Minister, Building Research Establishment, East Kilbride, Glasgow.

Filippidou, F., Nieboer, N., \& Visscher, H. (2016). Energy efficiency measures implemented in the Dutch non-profit housing sector. Energy and Buildings, 132, 107-116. https://doi. org/10.1016/j.enbuild.2016.05.095.

Fokaides, P. A., Maxoulis, C. N., Panayiotou, G. P., Neophytou, M. K. A., \& Kalogirou, S. A. (2011). Comparison between measured and calculated energy performance for dwellings in a summer dominant environment. Energy and Buildings, 43(11), 30993105. https://doi.org/10.1016/j.enbuild.2011.08.005.

Guerra-Santin, O. (2017). Relationship between building technologies, energy performance and occupancy in domestic buildings. In Living labs. Design and assessment of sustainable living. Editors: DV Keyson, O Guerra-Santin, D Lockton. Springer.

Guerra-Santin, O., \& Itard, L. C. M. (2010). Occupant's behaviour: determinants and effects on residential heating consumption. Building Research and Information, 38(3), 318-338. https://doi.org/10.1080/09613211003661074.

Guerra-Santin, O., \& Itard, L. C. M. (2012). The effect of energy performance regulations on energy consumption. Energy
Efficiency, 5(3), 269-282. https://doi.org/10.1007/s12053012-9147-9.

Guerra-Santin, O. \& Silvester, S. (2016). Development of Dutch occupancy and heating profiles for building simulation. Building Research \& Information, ISSN:0961-3218.

Guerra-Santin, O., \& Tweed, A. C. (2015a). In in-use monitoring of buildings: an overview of data collection methods. Energy and Buildings, 93, 189-207. https://doi.org/10.1016/j. enbuild.2015.02.042.

Guerra-Santin, O., \& Tweed, A. C. (2015b). In-use monitoring of buildings: an overview and classification of evaluation methods. Energy and Buildings, 86, 176-189.

Guerra-Santin, O., Romero Herrera, N., Cuerda, E., \& Keyson, D. (2016). Mixed methods approach to determine occupants' behaviour - analysis of two case studies. Energy and Buildings, 130, 546-566. https://doi.org/10.1016/j.enbuild.2016.08.084.

Hens, H., Parijs, W., \& Deurinck, M. (2010). Energy consumption for heating and rebound effects. Energy and Buildings, 42(1), 105-110. https://doi.org/10.1016/j.enbuild.2009.07.017.

Herring, H., \& Sorrell, S. (2009). Energy efficiency and sustainable consumption. The rebound effect. Energy, climate and the environment series. Palgrave Macmillan, UK, DOI: https://doi.org/10.1057/9780230583108.

Jong, A. d. (1992). Demonstration minimum energy renovation on basis of balanced ventilation and air heating. Kuiper Compagnons: Rotterdam.

Kane, T., Firth, S. K., \& Lomas, K. J. (2015). How are UK homes heated? A city-wide, socio-technical survey and implications for energy modelling. Energy and Buildings, 86, 817-832. https://doi.org/10.1016/j.enbuild.2014.10.011.

Konstantinou, T., Guerra-Santin, O., Azcarate-Aguerre, J., Klein, T., \& Silvester, S. (2017). A zero-energy refurbishment solution for residential apartment buildings by applying an integrated, prefabricated façade module. Munich: Paper presented at the PowerSkin.

Marszal, A. J., Heiselberd, P., Bourrelle, J. S., Musall, E., Voss, K., Sartori, I., \& Napolitano, A. (2011). Zero energy building-a review of definitions and calculation methodologies. Energy and Buildings, 43(4), 971-979. https://doi.org/10.1016/j. enbuild.2010.12.022.

Mathiesen, D., Lund, H., Paardekooper, S., Ridjan, I., Connolly, D., Thellufsen, J.Z., Jensen, J.S. (2016). Future green buildings: a key to cost-effective sustainable energy systems. Aalborg.

Matschoss, K., Atanasiu, B., Kranzl, L., \& Heiskanen, E. (2013). Energy renovations of EU multifamily buildings: do current policies target the real problems? Paper presented at the rethink, renew, restart. Eceee 2013 summer study.

McLoughlin, F., Duffy, A., \& Conlon, M. (2012). Characteristic domestic electricity consumption patterns by dwelling and occupant socio-economic variables: an Irish case study. Energy and Buildings, 48, 240-248. https://doi.org/10.1016 /j.enbuild.2012.01.037.

Meyers, R. J., Williams, D., \& Matthews, H. S. (2010). Scoping the potential of monitoring and control technologies to reduce energy use in homes. Energy and Buildings, 42(5), 563569. https://doi.org/10.1016/j.enbuild.2009.10.026.

Pretalogger (pretaloger.nl). Accessed on October 2015.

RVO, 2015-Utrecht www.rvo.nl

Sijpheer, N.C., Borsboom, W.A. and I.J. Opstelten. (2016). Results from first "NetZero Energy" projects in the Netherlands. Proceedings Suistainable Built Environment: 
Transition Zero, Eds. Opstelten I.J, Rovels R, Verdeyen, N. \& Wagenaar, A. Utrecht.

Silvester, S. (1991). EU-demonstration Project Minimum Energy Renovation, evaluation report occupancy study Schiedam. Rotterdam, Erasmus University Rotterdam. (1991).

Sociaal-Economische Raad. (2012). Ad hoc-Commissie Energie en, E. Naar een Energieakkoord voor duurzame groei. Den Haag.

Steensma, S., Konstantinou, T., Klein, T., Silvester, S., \& GuerraSantin, O. (2016). 2ndSkin, a business opportunity driven zero-energy apartment refurbishment approach in the Netherlands. In Proceedings conference Sustainable Built Environment: transition zero. Ed. Opstelten I, Rovers R, Verdeyen N \& Wagenaar A. Utrecht 7-8 April, 2016. ISBN/EAN: 978-90-815602-9-0 (E-Pub).

Stroomversnelling (http://www.stroomversnelling.net/). Accessed on October 2015.

Sunikka-Blank, M., \& Galvin, R. (2012). Introducing the prebound effect: the gap between performance and actual energy consumption. Building Research \& Information,
$40(3), 260-273$. https://doi.org/10.1080 /09613218.2012.690952.

Tigchelaar, C., \& Leidelmeijer, K. (2012). 2013. een samenspel van woning en bewoner-analyse van de module Energie WoON: Energiebesparing.

Virote, J., \& Neves-Silva, R. (2012). Stochatic models for building energy prediction based on occupant behaviour assessment. Energy and Buildings, 53, 183-193. https://doi.org/10.1016 j.enbuild.2012.06.001.

Wei, S., Jones, R., \& de Wilde, P. (2014). Driving factors for occupant-controlled space heating in residential buildings. Energy and Buildings, 70, 36-44. https://doi.org/10.1016/j. enbuild.2013.11.001.

Winter, R. E. A. (1993). Evaluatie van het E'novatioprogramma. Amsterdam, RIGO: RIGO.

Yohannis, Y. G., Mondol, J. D., Wright, A., \& Norton, B. (2008). Real-life energy use in the UK: how occupancy and dwelling characteristics affect domestic electricity use. Energy and Buildings, 40(6), 1053-1059. https://doi.org/10.1016/j. enbuild.2007.09.001. 